\title{
Adolescent Girls Initiative-Kenya: Financial Education Audio Training Script, Wajir
}

Population Council

Follow this and additional works at: https://knowledgecommons.popcouncil.org/departments_sbsr-pgy

Part of the Demography, Population, and Ecology Commons, Family, Life Course, and Society Commons, Gender and Sexuality Commons, and the International Public Health Commons How does access to this work benefit you? Let us know!

\section{Recommended Citation}

Adolescent Girls Initiative-Kenya: Financial Education Audio Training Script, Wajir. Nairobi: Population Council, 2017. 


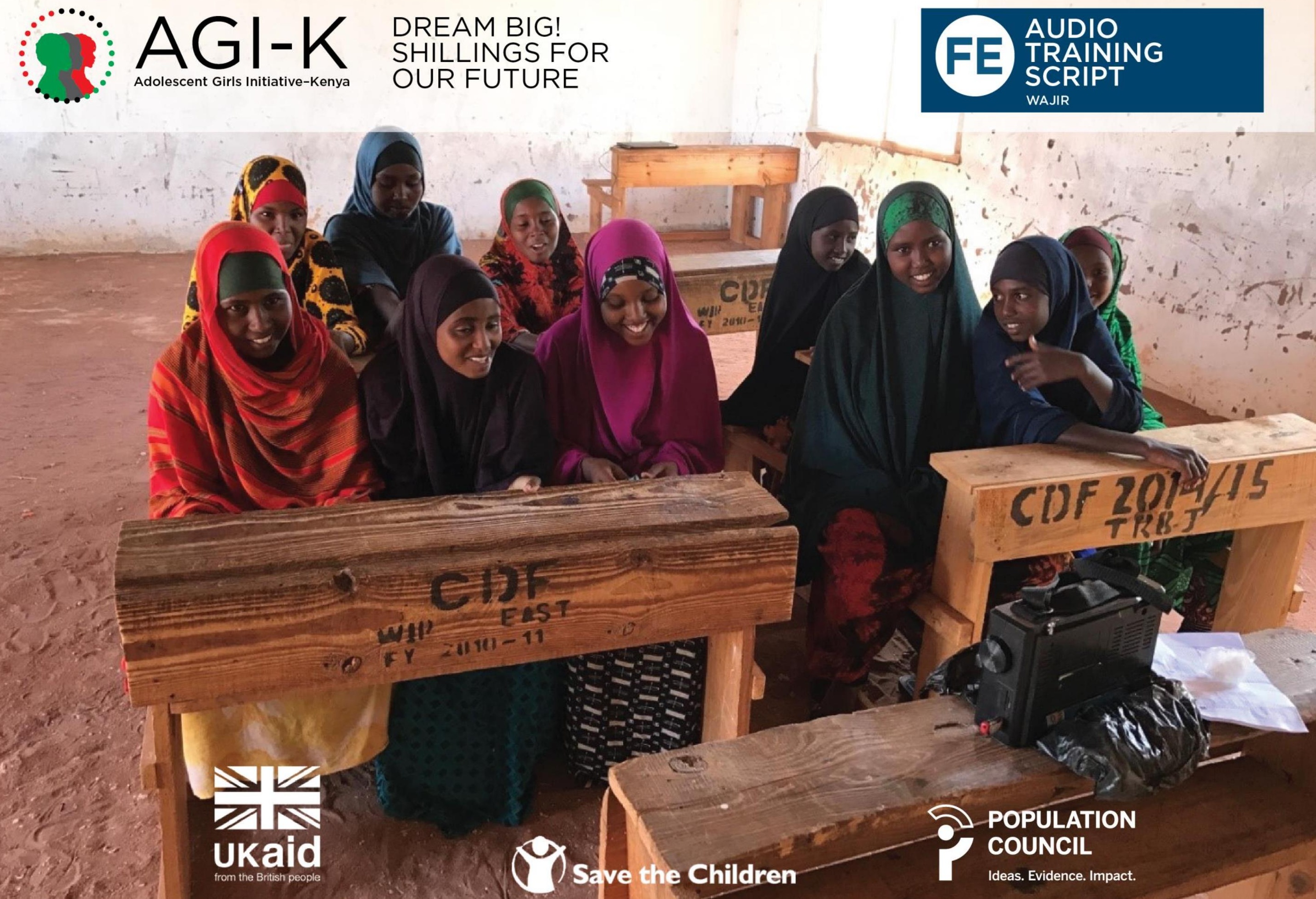




\section{POPULATION \\ COUNCIL \\ deas. Evidence. Impact.}

The Population Council confronts critical health and development issues-from stopping the spread of HIV to improving reproductive health and ensuring that young people lead full and productive lives. Through biomedical, social science, and public health research in 50 countries, we work with our partners to deliver solutions that lead to more effective policies, programs, and technologies that improve lives around the world. Established in 1952 and headquartered in New York, the Council is a nongovernmental, nonprofit organization governed by an international board of trustees.

\section{Population Council}

One Dag Hammarskjold Plaza

New York, NY 10017

Tel: 212-339-0500

Fax: 212-775-6092

www.popcouncil.org

Email: publications@popcouncil.org
Population Council - Kenya

General Accident House, 2nd floor

Ralph Bunche Road

PO Box 17643-00500

Nairobi, Kenya

Tel: +254202713480
Save the Children-Kenya

Matundu Close

Off School Lane, Westlands,

PO Box 39664-00623

Nairobi, Kenya

Tel: +254 20 4444006/

Written permission from the Population Council is required for any reproduction or distribution of more than fifty (50) copies per year, any electronic reproduction or any major change in content.

For inquiries regarding rights and permission, please contact publications@popcouncil.org

Sections of this book may be reproduced, translated or adapted with minor changes to meet local needs, provided they are distributed free or at cost and not for profit and provided that any changes maintain the integrity of the book. Please inform the Population Council of plans to translate these materials into another language and provide one (1) copy of the publication.

Please include the following statements on all section reproductions:

Reprinted from Population Council: Adolescent Girls Initiative-Kenya, Audio Training Script

(c) 2017 The Population Council, Inc. 


\section{Introduction}

The Adolescent Girls Initiative project-Kenya (AGI-K) helps young, vulnerable adolescent girls build their social, health, and economic assets. AGI-K tests combinations of interventions in health, violence prevention, wealth creation, and education to determine which package of interventions delivers the most impact and at what cost. The project was led by Population Council and implemented in two marginalized areas 1) Kibera in Nairobi and 2) Wajir County in Northeastern Kenya by Plan International and Save the Children respectively.

The wealth creation intervention focused on training girls on financial education as well as providing a saving component for them to practice skills gained from the sessions. Groups of girls about 25-30 would meet on a weekly basis in a safe and fun setting to benefit from financial education sessions under the leadership of a trained mentor.

This scripted guide was designed to support the delivery of the financial education sessions in Wajir. The shift from face-to-face training to audio sessions was in response to challenges with mentor capacity in this very remote, rural, underserved setting. The scripts were adapted from the written Wajir financial education curriculum, translated into Somali language and recorded in form of audio. The audios were helpful in guiding mentors to effectively facilitate sessions among girls aged 11-14 but can be adapted for girls in other age categories.

\section{Purpose and use of the guide}

The scripted sessions are useful in developing audio facilitation tools for facilitators that need support to effectively deliver training content. The audios act as an effective tool to enhance learning of financial education in a fun and engaging manner.

It is recommended that mentors/ facilitators undergo a comprehensive in-person training on the key financial education components: savings, earning money, budgeting, spending money and the risky income cycle. The training is useful in building comprehensive skills and knowledge on financial education. The Wajir financial education curriculum can be used/ adapted to train mentors/facilitators as the audio scripts in this guide were adapted from the curricula. Training should include practical sessions on facilitation techniques using the audios.

\section{Adaptation process and recording of audios}

The scripted sessions in this guide can be adapted to suit program needs and translated into a local language ${ }^{1}$ that resonates with the participants and facilitators. During translation and recording efforts should be made to ensure that content in the original/ adapted scripts is not distorted. Quality of content can be enhanced by engaging a translator, reviewer of the translations and audios.

Pre-testing of some audio sessions with the target group is recommended as part of quality assurance prior to rollout of the tool.

${ }^{1}$ Contact Population Council at publications@popcouncil.org to obtain the recordings in Somali language. 


\section{Structure of sessions}

The manual has 20 scripted sessions outlined in form of narrations. The step by step narration is organized in a systematic format that guides the facilitator on how to deliver content and conduct interactive learning exercises. The sessions therefore position the facilitator and participants as central and active persons in the learning process. At the end of each session, key learnings are summarized by the narrator. This approach is crucial in ensuring that the target group gains correct and factual content.

Each session is outlined as follows;

$\checkmark$ Session Title: the session title names the main topic covered in the session.

$\checkmark$ Session objectives: provides an overview of session and purpose.

$\checkmark$ Reflection on the previous sessions: provides an opportunity for participants to remind themselves what they learnt in the previous session and for the facilitator to clarify any confusing issues.

$\checkmark$ Materials required: Outlines training aids needed to effectively carry out exercises in the session. Facilitators can utilize facilitation aids inform of pictorials where applicable.

$\checkmark$ Time: provides a general timeframe of each session.

$\checkmark$ Energizers: can be carried out as the first activity in each session. However, the facilitator can pause the audio at any point to conduct an energizer. The energizer can be led by the facilitator or a participant.

$\checkmark$ Activities: have been organized in a simple step by step interactive format. The activities have been designed to address session objectives.

$\checkmark$ Pause function: each scripted session has a "pause" function that guides the facilitator on points of pausing the audio for purposes of engaging participants in specific activities. The facilitator has the liberty to pause the audio at any point of facilitation to clarify any confusing issues, respond to questions or conduct an energizer.

\section{Pre-session Preparation}

Prior preparation to each session is crucial. Being prepared for the learning session will give the facilitator confidence to effectively facilitate the session. Preparation entails listening to the entire audio session, practicing and preparation of relevant training materials. 


\section{Table of Contents}

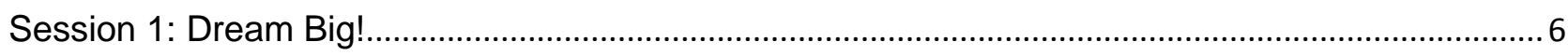

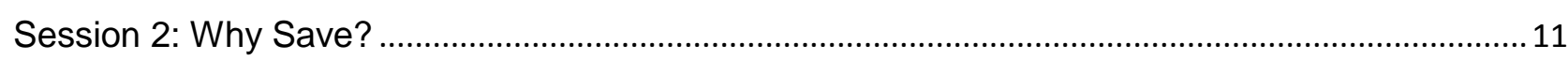

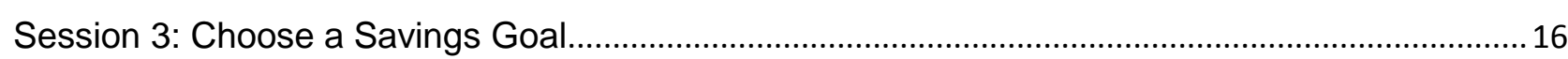

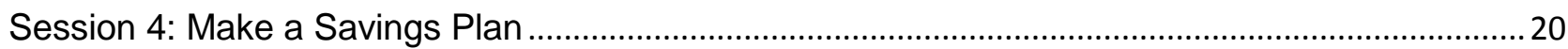

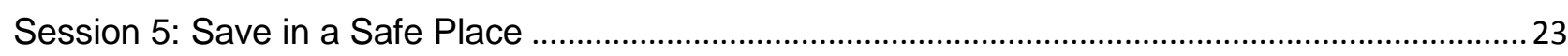

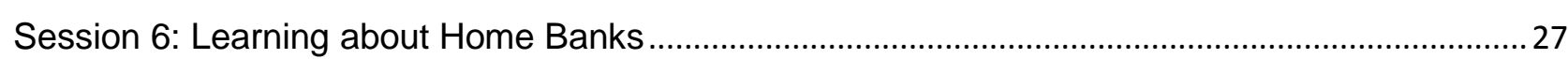

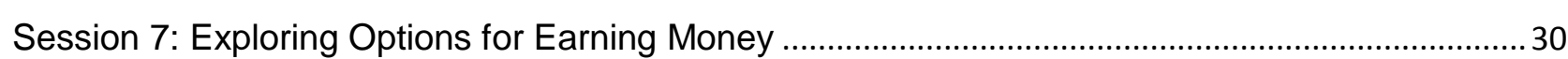

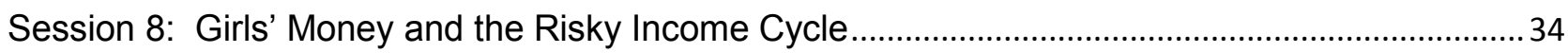

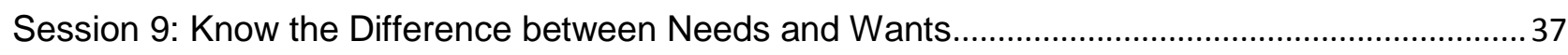

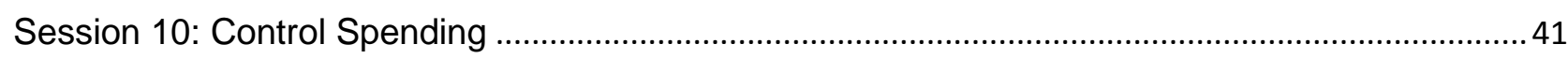

Session 11: Think About the Future: Money in and Money Out .........................................................4 4

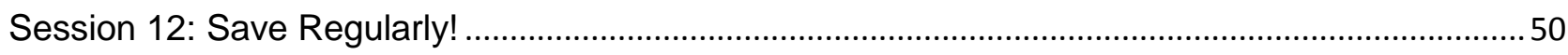

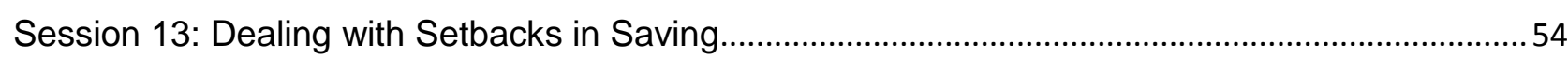

Session 14: Your Own Money vs. Someone Else's Money ...............................................................57

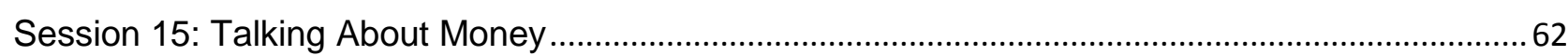

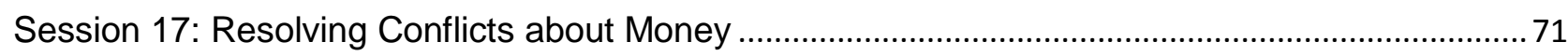

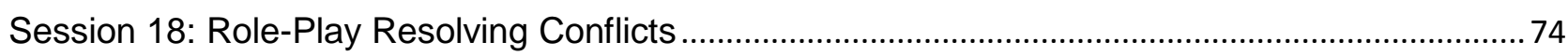

Session 19: Our Journey to Good Money Management........................................................................ 77

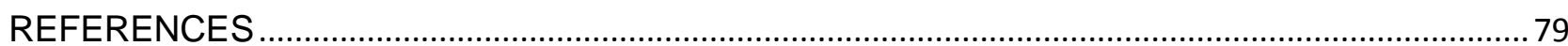


Narrator: Hello, girls, welcome to today's session. In this session, we will talk about our dreams for the future.

Narrator: Mentor, for this session you will need a blackboard and chalk OR flipchart.

Narrator: The session will take about 1 hour and 30 minutes.

(II) Narrator: Mentor, pause and ask the participants to share what they learned in the last session. Be sure to clarify any confusing issues.

Narrator: Before, we begin the session, let us have a volunteer to lead us in an energizer. We. Mentor, pause an invite one of the participants to lead the rest in an energizer.

Narrator: One of the purpose of meeting in our Safe Spaces group to support each other, and to learn about how to make good decisions about our lives. In our safe spaces, we will learn about how to plan for and make good use of our money. This is because money is important when it comes to making choices. This type of learning or training is called "financial education."

(II) Narrator: I want you to think about your dreams. Close your eyes for just a moment. Mentor, pause and instruct the girls to close their eyes.

Narrator: I hope we have all closed our eyes. Now, think about how old you are now. How old will you be in five years' time? Think about yourself 5 years from now when you are older. Where are you living? What are you doing? What goals or plans have you achieved?

(II) Narrator: Now, I want you to think about one specific dream you want to achieve in 5 years' time. Got it? Mentor, pause and allow the participants 2 minutes to reflect on their dreams.

(II) Narrator: Mentor, pause and ask 3-4 volunteers to share their dreams.

(II) Narrator: Now that we have all thought about some of our dreams I want everyone to stand up and clap if reaching your dream will involve having some money. Mentor, pause. And allow the girls to stand up and clap.

Narrator: As we can see, most of our dreams require some money to be reached. So we need to be wise about how we earn, spend, and save our money so that our dreams can become true 
Narrator: If we want to achieve our dreams, we have to plan and prepare using our good judgment - including how we manage our money. I am going to tell you the story of a childhood friend called Zahra.

Narrator: Let's listen to the story of Zahra. While you listen, think about how she prepares for her future, and what some of the things both inside her, and around her, that either support or block her as she tries to achieve her dreams

\section{ZAHARA'S STORY}

Zahra is 12 years old, and the oldest in her family. She stays with her mother and her three sisters in a two-room 'manyatta'. Her mother struggles to buy food and also cloth her girls but she is proud of Zahra since she is so helpful with housework. Zahra even earns some money to help the family by washing clothes for an elderly neighbor and by selling sweets to other pupils at her school.

Luckily, Zahra and her sisters are smart, and Zahra's mother was helped by the local mosque with scholarships. All four of her children got sponsors who pay school fees for them in a nearby day school-though Zahra has to use some of the money she earns to buy school supplies.

As a young girl Zahra always told her mother that she wanted to be a henna artist, just like the Famous Farhia. Her mother always tells her: "that is not a future job for a person I gave birth to!" So every time Zahra would run to her friend's place and practice applying henna without her mother's knowledge. She also used some of the money she earned to buy refreshments for her friends at schooleven if it meant not being able to buy all of the school supplies she needed, or saving any money to buy new henna like she wanted to.

When Zahra reached class 6, she dropped out of school. Even when her mother pleaded with her to stay in school and reminded her about her sponsorship she refused.

One of her friends from the henna art group said she knew about a way she could make "easy money" and tricked her into leaving home and becoming a wedding henna artist. Zahra's mum promised not to give up on her daughter so she visited a youth center and talked to the staff who agreed to help her find Zahra and also provide counseling Services. Finally she came back home and they trained her to be a professional henna artist.

Zahra is now one of the prominent henna artists in her village that is sponsored by the youth center. 
Narrator: Thank you for listening to Zahra's story. I will now ask you some questions about the story. Please pay attention.

(II) Narrator: What happened in this story? Who can tell me in her own words? Mentor, pause and select one participant to narrate the story.

(II) Narrator: What is Zahra's dream? Mentor, pause and listen to the responses.

Narrator: Very good. Zahara's dream is to become henna artist.

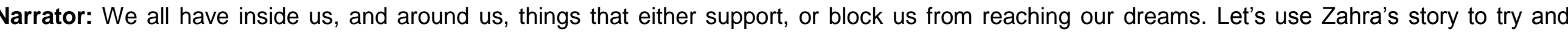
understand what this means, and why it is important to think about Strengths, Weaknesses, Opportunities, Threats.

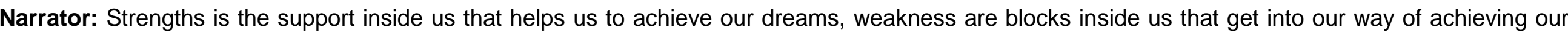

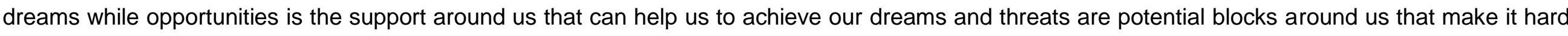
for us to achieve oure dreams.

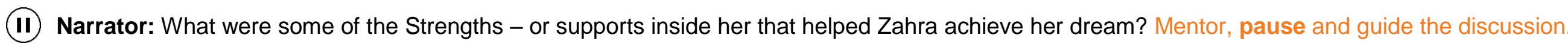

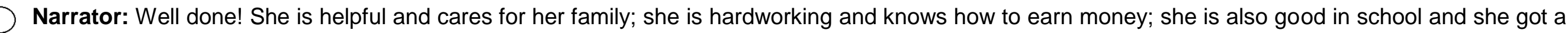
scholarship.

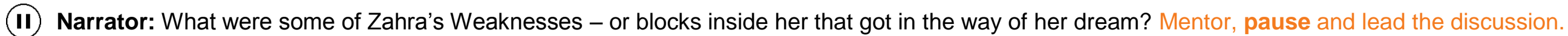

Narrator: Zahara was stubborn, and made a bad decision to drop out of school to become a henna artist.

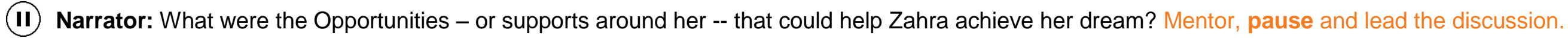

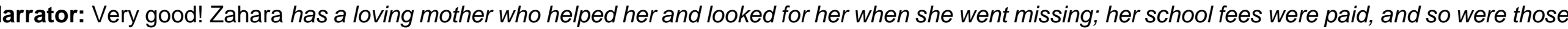
of her sister; there is a youth center in her community that counseled her and helped her with training to be a professional henna artist.

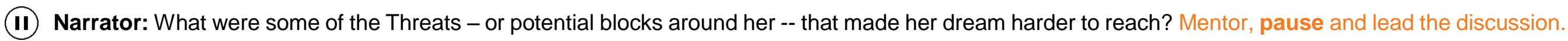

Narrator: Zahara's family is struggling with money. 
Narrator: As we have just explored through Zahra's story, if we want to reach our dreams we have to think carefully about the things inside us, and the things around us that can either support us or block us.

(II) Narrator: We will now learn how to identify our strength, weaknesses, threats and opportunities using a SWOT diagram. Mentor, pause and draw a square on the blackboard or flipchart and divide the square into 4 equal parts. Write at the top of one part of the square - strength, on another weakness, the next opportunities and the last part write threat.

Narrator: Once you have drawn, divided and labelled all the 4 parts of the square, pause and instruct the participants to draw something similar on their note books.

(II) Narrator: I hope we have all drawn our squares. I want you to continue to think about the dream you just chose earlier in today's session - and I want you to work with a partner to try and identify some of the Strengths, Weaknesses, Opportunities, and Threats that might impact you reaching your dream. Mentor, pause and make sure all girls have a partner.

II Narrator: I hope we all have a partner. Let's start by speaking to our partner about some of our Strengths - or things I have inside me that might help me to achieve my dream. Strengths are all the things you are good at or things that you have within you that could help you achieve your goals. They could be part of your personality, skills that you have or things that you are good at. Mentor, pause and allow the participants 3 minutes to write their strengths on the strength section on the square and share with their partners.

(11) Narrator: Now, even though this might be hard to do at first, let's speak to our partner about some of our Weaknesses - or the things inside me that might block me from reaching my dream. Weaknesses are things about you that you may need to work on - or to improve - to achieve your dream. For example, you may not be good at time management, do not know how to use a computer very well or even that you are poor in skinning animals or preparing traditional drinks. Mentor, pause and allow the participants 3 minutes to write their weaknesses on the weaknesses section on the square and share with their partners.

(II) Narrator: Next, let's share a few examples of our Opportunities - or some of the things around me that might help me to achieve my dream. An opportunity could be something like: computer classes are being offered next month at a discount in Wajir town. Or, you have seen that there is a need for more tailors in your neighborhood. This means that you could take a computer class for a cheaper price, or that you could make money as a tailor, for example. Mentor, pause and allow the participants 3 minutes to write their opportunities on the opportunities section on the square and share with their partners. 
(11) Narrator: Finally, and again this might be hard, let's speak to our partner about some of our Threats - or things around me that might block me from reaching my dream. This is anything outside you - in your neighborhood, at your school, in your family - that is a challenge. If you have a small shop, a threat to your success is if there are many other people selling the same things near you. That means that you might not have good business. Another example that girls have mentioned in other classes is an unplanned pregnancy. If you become pregnant or have a child before you are ready, you might have to stop studying. This means that you might not realize your dream of finishing secondary school. Mentor, pause and allow the participants 3 minutes to write their threats on the threats section on the square and share with their partners.

(II) Narrator: Mentor, please pause and invite girls to ask any questions they might have about using a SWOT Diagram.

Narrator: It is important that when you make plans to achieve your dreams you think about what will help you and what might make it harder for you. That way you can take advantage of the good things and plan how to work with the things that might be hard. Over the next several sessions we'll talk a lot more about your dreams, plans, and goals for the future, especially those related to money, so we can all achieve those dreams.

(11) Narrator: We are almost coming to the end of today's session. Mentor, please pause and respond to questions from the participants. Please remember to clarify any confusing issues.

Narrator: I hope you enjoyed today's session. 


\section{Session 2: Why Save?}

Narrator: Hello, today we will begin the session in our financial education program. The goal is to learn one important way of managing our money. We will start by talking about putting money aside because it is the key to being wise about money. We call "putting money aside" saving. Later on, we will also talk about other things related to money - like how to talk to other people about money and different ways to earn money.

Narrator: Mentor, for this session you will need a blackboard, chalk OR flipchart markers and a Soft ball, rolled up sock that can be easily tossed among the participants

Narrator: The session will take about 1 hour and 30 minutes.

III Narrator: Mentor, pause and ask the participants to share what they learned in the last session. Be sure to clarify any confusing issues.

(II) Narrator: Before, we begin the session, let us have a volunteer to lead us in an energizer. Mentor, pause an invite one of the participants to lead the rest in an energizer. Remember, you can always pause the recording at any point of the session and conduct an energizer.

Narrator: We will start the session with a short activity to find out a little more about what managing money really means. I am going to say a series of statements and ask you to stand up for each one that is true for you.

(II) Narrator: Stand up if you walked here today. Mentor, pause and give the participants time to stand up.

(II) Narrator: Stand up if you are wearing green. Mentor, pause and give the participants time to stand up.

(II) Narrator: Stand up if you have never saved money before AGI-K. Mentor, pause and give the participants time to stand up.

(II) Narrator: Stand up if you like to spend money. Mentor, pause and give the participants time to stand up.

(II) Narrator: Stand up if you know how much you spent on food last week. Mentor, pause and give the participants time to stand up.

(II) Narrator: Stand up if you wish you had more money. Mentor, pause and give the participants time to stand up.

(II) Narrator: Stand up if you are saving for something specific you want. Mentor, pause and give the participants time to stand up.

(II) Narrator: Stand up if you think saving is important. Mentor, pause and give the participants time to stand up.

(II) Narrator: Stand up if you think saving money is difficult. Mentor, pause and give the participants time to stand up. 
(II) Narrator: For those of you who think that saving is important, why do you think so? Mentor, pause and guide the discussion.

Narrator: Saving helps you to use your money better, helps you depend less on other people, makes you feel secure when you have a problem and need money, helps you to plan for the future and achieve those plans.

(II) Narrator: Why is saving money difficult? Mentor, pause and lead the discussion.

Narrator: Saving money can be difficult if you do not have regular income, do not have any extra money, give any leftover money to parents for household expenses, spend extra money on things like sweets or make-up, do not have a safe place to keep money aside.

(II) Narrator: What would make you want to save money? Mentor, pause and give the participants time to stand up.

Narrator: One would want to save to; take care of personal needs/wants, avoid depending on other people, be able to make own decisions, help out family in household needs.

(II) Narrator: What would make you not want to save money? Mentor, pause and lead the discussion

Narrator: One would not want to save if; It is not safe to save, you can lose your money, money is too little to save, don't know how to save.

\section{Narrator: Managing money involves all these things:}
1. saving money
2. spending money
3. planning how you will spend your money, and
4. Keeping track of how you spend your money.

Narrator: Since most of us do not have enough money to pay for everything we need and want, we have to make choices about what we will buy and what we won't. We try to save for things we will want in the future. We figure out how to stretch our money to cover the necessary expenses we face. It can be hard.

Narrator: In the next few sessions, we will focus on the value of saving, and learn things we can do to help us save. We call these the "Eight Steps for Savings". 
Narrator: The eight steps of savings are;

1. Choose a Savings Goal

2. Make a Savings Plan

3. Know the Difference Between Wants and Needs

4. Control Spending

5. Think About the Future: Money In and Money Out

6. Save Regularly

7. Save in a Safe Place

8. Deal with Setbacks in Saving

II Narrator: In the course of learning about financial education, we will review each step of saving. The mentor will assign each one of you one step of saving which you will be expected to recite. Mentor, please pause and assign each girl one step of savings. Once you have assigned each one of them, ask them to recite back.

II Narrator: We will now play a game called pass the ball to help us understand why we should save. Mentor, for this game, you will need a soft ball, rolled up sock that can be easily tossed among the participants Mentor, pause and ask participants to stand and form a circle.

(II) Narrator: I will now explain how we will play the game. Please pay attention. I will read out a sentence that is unfinished and then the mentor will a ball to someone in the circle. The girl who catches the ball will repeat the beginning part of the sentence I would have started and 'answer' it, or complete the sentence then throw it to another girl until we finish all the sentences are answered. Mentor, pause and explain the game.

Narrator: Before we begin the game, I will give you an example. If I read out a sentence like "girls my age save money to A girl who catches the ball can respond as follow;

Girls my age save money to buy a hijab. I hope we have now understood the game. Are you ready to play?

III Narrator: The first sentence is; Girls my age save to Mentor, pause and throw the ball to one participant who will complete the sentence. The ball can be thrown to at least 4 participants to complete the sentence. 
(II) Narrator: The second question is; Boys my age save to Mentor, pause and throw the ball to one participant who will complete the sentence. The ball can be thrown to at least 4 participants to complete the sentence.

(II) Narrator: The third question is; Girls my age save to Mentor, pause and throw the ball to one participant who will complete the sentence. The ball can be thrown to at least 4 participants to complete the sentence.

(II) Narrator: The fourth question is; Adults often save to Mentor, pause and throw the ball to one participant who will complete the sentence. The ball can be thrown to at least 4 participants to complete the sentence.

(II) Narrator: The last question is; Adults often save to The ball can be thrown to at least 4 participants to complete the sentence.

Mentor, pause and throw the ball to one participant who will complete the sentence.

Narrator: You have named many different reasons to save. Most will relate to one of the following "main reasons" (or "categories") for saving. The first main reason is: Personal or family use, which can include food, clothes, rent, or snacks.

(II) Narrator: What are other examples of "personal or family use"? Mentor, pause and guide the discussion.

Narrator: Some examples of personal or family use are; Hair maintenance, sanitary towels ${ }_{1}$ lotion, firewood, kerosene, etc.]

Narrator: The second main reason is: Emergencies, those unexpected events that we need to deal with right away. Some examples are illness, accidents, or natural disasters.

(11) Narrator: What other emergencies can we save for? Mentor, pause and guide the discussion

Narrator: We can save for emergencies such as; Theft, fire, parent loses a job, drought (?), etc.].

Narrator: The third main reason is: Future opportunities, like those ideas some of you have for the future. We can save to meet these goals. We might save money for school fees, get training in a skill or trade, the next planting season, move into our own house/room, or start a business.

(II) Narrator: What other future opportunities can we save for? Mentor, pause and guide the discussion.

Narrator: Some future opportunities that one can save for are; education, wedding, training or skills school, purchase jewelry, children's educations, a house or land, a lump sum of money to start a business, etc. 
(11) Narrator: Mentor, please pause and write Personal use, emergencies and Future opportunities on 3 different pieces of paper then post the papers on 3 different spots. If you are inside, you can use a corner, the door, a window; if you are outside, select or mark 3 distinct spots - for example, near a tree, bush or rock - close by). Point out the 3 places to the participants.

(11) Narrator: Girls, your job is to decide which of these main reasons or "categories" of reasons to save is the highest priority for you. Choose one, and go stand in the location assigned the category you have selected as your most important reason to save. Mentor pause and give the participants 15 seconds to make your choice and move!

(11) Narrator: I hope everyone has moved to the place that marks the savings category of their choice. Mentor, pause and allow the participants 2 minutes to share with the others who have chosen the same priority why they think this reason to save is the most important. Mentor, if all the girls move to 1 or 2 of the categories, you will have to ask for volunteers to "choose" the one that has not been selected and ask them to move to the spot that does not have enough people. When the discussion is over, ask the participants to sit down.

Narrator: You might have guessed by now that there is no wrong answer for which of these categories are most important. They are all good reasons to save, and the importance depends on the individual's or family's wants and needs. The level of importance might also change over time. But in reality, it can be difficult to save for all three. Sometimes you have to decide what is most important to you.

II Narrator: What happens when girls need money for these things, like personal needs or to deal with an emergency, but she does not have money of her own? Mentor, pause and lead the discussion.

Narrator: Sometimes, when girls need money to buy personal items, help their family with food or rent, or to manage an emergency that might come up, if they do not have their own money saved up that they can use, they find other ways to get that money. Like borrowing money and they have no means to return. So, one important reason to save is that when these needs come up - personal items, future use, or emergencies - you have your own money to use instead of putting yourself in a potentially risky situation to get money. We will talk more about this in the coming sessions.

Narrator: We are almost coming to the end of today's session. The mentor will now pause, answer your questions and respond to any confusing issues.

Narrator: Thank you for participating in today's session. See you next week! 


\section{Session 3: Choose a Savings Goal}

Narrator: Hello, girls, welcome to today's session. In this session, we will learn how to choose a savings goal.

Narrator: Mentor, for this session you will need a blackboard / chalk OR flipchart and the a list of the eight steps of saving written on a flip chart.

Narrator: The session will take about 1 hour and 30 minutes.

(II) Narrator: Mentor, pause and ask the participants to share what they learned in the last session. Be sure to clarify any confusing issues.

(II) Narrator: Before, we begin the session, let us have a volunteer to lead us in an energizer. We. Mentor, pause an invite one of the participants to lead the rest in an energizer.

Narrator: During the last session, we talked about the eight steps of saving which are;

1. Choose a Savings Goal

2. Make a Savings Plan

3. Know the Difference Between Wants and Needs

4. Control Spending

5. Think About the Future: Money In and Money Out

6. Save Regularly

7. Save in a Safe Place

8. Deal with Setbacks in Saving

II Narrator: We also talked about why saving is good. Can someone remind us the 3 categories of saving that we talked about in our last meeting? Mentor, pause and lead the discussion.

\section{Narrator: The 3 categories of savings are;}
1. Personal use
2. Family use and
3. Emergencies 
Narrator: As we know, savings can help us start a business or respond to an emergency or buy something we really want. We also know how hard saving money can be. To make it easier, we are going to talk about eight steps we can use to help us save.

(II) Narrator: If you remember, I the mentor you each a step to remember in the first session. We will talk about one strategy each week until we've reviewed them all! Now, the mentor will pause and each one of you will recite the step that was assigned to you. Mentor, please pause and make sure that all the steps have been mentioned.

(II) Narrator: Thank you for reciting the eight steps of saving. Now, what is a goal? Mentor, pause and listen to the responses.

(II) Narrator: Remember your dreams about the future from the beginning of our sessions in financial education? What are some of your dreams? Mentor, pause and give some volunteers to share their dreams with the rest of the participants.

Narrator: These dreams about the future can be called goals. A goal is something you want to achieve in the future - perhaps in school, perhaps related to your family, perhaps in your work. A goal might be to visit a relative who lives in another place, or to learn a new skill, like sewing, skin art (henna art) among others.

Narrator: Goals that involve what we want to do with the money we save are savings goals. I am going to read a short story about a girl your age. Her name is Amina. As you listen to the story, pick out her goals on money.

\section{AMINA'S STORY}

Amina is 12 years old and lives with her mother and younger brother. Her older sister, Halima is married and lives in Garissa town. Halima just had a baby girl, and Amina is eager to visit, to spend time with the baby, and help her sister.

Amina will need money for transport and a small gift for the baby. A cute baby shawl would be perfect! But she can't take money from her home bank for this trip because she is saving that money to buy new school shoes. Amina's dream is save enough money to buy herself shoes so that she can finally stop going to school bare foot. She hopes that her uncle will ask her to fetch water for his cattle so that she can get the money she needs for the trip. 
Narrator: I hope you enjoyed listening to Amina's story. I will now ask you some questions related to the story.

(II) Narrator: What are Amina's savings goals? Mentor, pause and guide the discussion.

Narrator: Amina's savings goals are transport to her sister's town, a gift for her sister's baby, money to buy shoes.

(II) Narrator: Which of her savings goals can be met within a few weeks? Mentor, pause and lead the discussion.

Narrator: The savings goals that can be met within a few weeks are; transport money, the baby gift.

(II) Narrator: Which savings goal will take a longer time? Mentor, pause and lead the discussion.

Narrator: The savings goal that will take a longer time is money for shoes.

(II) Narrator: What can Amina do to meet her goals? Mentor, pause and lead the discussion.

Narrator: Good, Amina can; ask for many different solutions from participants such as different jobs she could do, expenses she could cut down on, for her to meet her goals.

Narrator: What are your savings goals? Mentor and guide the discussion.

(II) Narrator: Like Amina, many of you hope to achieve something by saving. First, close your eyes and think of one savings goal you have that you can achieve in a relatively short time - within the next 1-2 months. Got it? That is your first goal. Okay - keep it in your mind for just a moment! Mentor, pause and let the girls close their eyes for 30 seconds.

III Narrator: Now, think about a different goal, something you want to be able to purchase that will probably take you a little longer - like 1-2 years - to save for. Mentor, pause and let the girls close their eyes for 30 seconds.

(II) Narrator: Now, turn to your neighbor and share with each other your 2 goals. Mentor, pause and allow the girls to share for 1 minutes.

(II) Narrator: Mentor, pause and ask $3-4$ girls to share their goals with the larger group. 
Narrator: The first savings goal you just thought of - the goal that will take you just a few months, can be called a short-term goal. You can achieve shortterm goals in a relatively short amount of time.

Narrator: The second savings goal you just thought of - the one that will take a year, or more! - is a long-term goal. This goal is like a big dream that you can achieve some time in the future.

(II) Narrator: How can having a savings goal help you to save? Mentor, pause and led the discussion.

Narrator: A savings goal can help you to save when you are saving for something that you really want, or that is really important to you, you are motivated to save and have discipline to control your spending.

Narrator: Between now and our next meeting, think about your savings goals every day!

(11) Narrator: We are almost coming to the end of today's session. Mentor, please pause and respond to questions from the participants. Please remember to clarify any confusing issues.

Narrator: I hope you enjoyed today's session. 


\section{Session 4: Make a Savings Plan}

Narrator: Hello, girls, welcome to today's session. In this session, we will learn how to make a savings plan.

Narrator: Mentor, for this session you will need a blackboard / chalk OR flipchart

Narrator: The session will take about 1 hour and 30 minutes.

(11) Narrator: Mentor, pause and ask the participants to share what they learned in the last session. Be sure to clarify any confusing issues.

(II) Narrator: Before, we begin the session, let us have a volunteer to lead us in an energizer. Mentor, pause an invite one of the participants to lead the rest in an energizer.

Narrator: We will begin the session by reminding ourselves about savings goals.

(II) Narrator: What is a savings goal? Mentor, pause and lead the discussion.

Narrator: A savings goal is something you save money for. It can be something big or small you want to buy, or a trip you want to take.

(II) Narrator: What are some of your "small" savings goals? Mentor, pause and lead the discussion.

(II) Narrator: What are some of your "big" savings goals? Mentor, pause and lead the discussion.

(II) Narrator: We will now divide ourselves into 3-4 groups for a group activity. Mentor, pause and divide the participants.

Narrator: I hope we are all in groups. Today we will learn how to make a savings plan. I will assign each a savings goal for this activity. Please take out your

Narrator: Group one, your savings goal is to buy a hijab.

$\checkmark$ How much money do you need to buy a hijab?

$\checkmark$ How much money do you think you can save each week to buy the hijab?

$\checkmark$ How many weeks will it then take you to buy a hijab? 
Narrator: Group two, your savings goal is to buy a goat.

$\checkmark$ How much money do you need to buy a goat?

$\checkmark$ How much money do you think you can save each week to buy the goat?

$\checkmark$ How many weeks will it then take you to buy a goat?

Narrator: Group three, your savings goal is to buy lotion.

$\checkmark$ How much money do you need to buy a lotion?

$\checkmark$ How much money do you think you can save each week to buy the lotion?

$\checkmark$ How many weeks will it then take you to buy a lotion?

Narrator: Group four, your savings goal is to buy a mobile phone.

$\checkmark$ How much money do you need to buy a mobile phone?

$\checkmark$ How much money do you think you can save each week to buy the mobile phone?

$\checkmark$ How many weeks will it then take you to buy a mobile phone?

Narrator: Before you begin your group work, I would like to give you an example. Please pay attention. If for example a girl has a savings goal of buying a pair of new shows shoes, she might need Kshs 500 for the shoes, she might be able to save Kshs 50 per week. So she will need divide the amount (Kshs 500 ) by the amount she can save per week (Kshs 50) for her to get 10 weeks which is the time she needs to save.

Narrator: For you to get the number of weeks needed to save for your savings goal, you will need to divided what I plan to save by what I can save each week. I hope the exercise is now clear.

Narrator: We have just made a savings plan for a girl like us who wants to buy a pair of new shoes. Now, do the same for the savings goal you have been assigned

- Decide how much money you will need for your savings goal in total.

- Agree on how much money you could save each week

- Using that number, decide how many weeks you will need to save for to reach your savings goal.

(II) Mentor, please pause and allocate the groups 10 minutes for the group work. While the girls are talking, circulate to make sure that everyone understands the task.

(II) Narrator: Mentor, pause and ask the groups to share their savings plan with the larger group. 
Narrator: Thank you for sharing your plans. I will now ask you some questions regarding the presentations.

(II) Narrator: Where the prices of the items the groups intended to buy realistic? Mentor, pause and lead the discussion.

(II) Narrator: Is the amount they plan to save each week realistic? Mentor, pause and lead the discussion.

(II) Narrator: What would happen if they could save more or less money, each week? Mentor pause and lead the discussion.

Narrator: If the groups saved more, they would reach their goal in fewer weeks and if they saved less it would take more weeks to reach their goal.

(II) Narrator: What could you do if you needed to reach your savings goal faster? Mentor, pause and lead the discussion.

Narrator: If you needed to reach a savings goal faster, you would save more each week; Change the goal to be less costly.

(II) Narrator: What should they do if they decide to save money every day, instead of every week? Mentor, pause and lead the discussion.

Narrator: They should do the same calculations, but then it will give them the number of days it will take to reach their goal instead of weeks.

(II) Narrator: How do you think a savings plan can help you to save? Mentor, pause and lead the discussion.

Narrator: Remember you can use the same skill you have gained from the group work to develop your personal savings plan for both short term and long term goals.

(II) Narrator: We are almost coming to the end of today's session. The mentor will pause and respond to any questions and clarifications.

Narrator: I hope you have gained an important skill of how to develop a saving plan. Thank you for participating and see you next week! 


\section{Session 5: Save in a Safe Place}

Narrator: Hello! Welcome to today's session. In this session, we will discuss about safe places at home where we can keep our savings.

Narrator: Mentor, for this session you will need a blackboard, chalk OR flipchart markers

Narrator: The session will take about 1 hour and 30 minutes.

(11) Narrator: Mentor, pause and ask the participants to share what they learned in the last session. Be sure to clarify any confusing issues.

(II) Narrator: Before, we begin the session, let us have a volunteer to lead us in an energizer. Mentor, pause an invite one of the participants to lead the rest in an energizer. Remember, you can always pause the recording at any point of the session and conduct an energizer.

Narrator: Saving can be difficult because there are so many demands on our money. When we are able to save, it is important to put our savings someplace safe, where they cannot be taken by someone else, and where we ourselves will be less tempted to spend them. Our "Savings Step of the Day" is: Save in a Safe Place!

(II) Narrator: What makes a place safe for keeping money? Mentor, pause and lead the discussion.

Narrator: A safe place for keeping money can be a place where nobody else knows about, where only you have access to the money, where only you can decide what to do with the money and when, where the money will not be stolen.

Narrator: Now, I will tell you a story about a girl called Rafiqah who is 11 years old and lives in Griftu. Her grandmother gave her and her cousins Kshs 50 each for Id UI Fitr, Rafiqah plans to save this money to reach important goals. Please pay attention because I will ask you questions at the end of the story. 


\section{The Story of Rafiqah}

Rafiqah is a girl with a dream: she has planned to buy school items like pencils and drawing books because she likes drawing. Rafiqah keeps her savings in her home bank. Rafiqah's home bank is hidden in a safe place where no one can see it so it cannot be stolen. She puts the 50 Shillings from her grandmother in her home bank. Rafiqah wants to have some money to continue depositing and keep saving up until she has enough for the drawing materials- which cost 100 Shillings.

She saves some little money which she is paid by her uncle for fetching water for her uncle's goats over the weekend like 5 shillings or sometimes 10 shillings. When Rafiqah's brother gets married, she really wants a new dress for the wedding. However, seeing her savings growing in her home bank encourages her not to take the money out, so she is able to decide not to buy a new dress. However, she did use some of the money in her home bank one day to buy some sweets. One day, her younger brother comes and demands some money from her, but because the home bank is hidden away and no one knows about it, she does not have to part with any money.

Another day, Rafiqah's mother asks for 10 Shillings to buy some sugar, and Rafiqah wanted to help her mom so she went into her home bank and gave her the money. Even though it took a couple of months, Rafiqah was able to save 100 shillings in her home bank and she went and got the school supplies that she needed.

(II) Narrator: What are Rafiqah's savings goals? Mentor, pause and guide the discussion.

Narrator: Rafigah's savings goals were to buy pencils and drawing book.

(II) Narrator: How does Rafiqah get the money to save and achieve her goals? Mentor, pause and guide the discussion.

Narrator: Rafigah gets money from fetching water for her uncle's goats.

(II) Narrator: How will having a home bank help Rafiqah to reach her goals? Mentor, pause and guide the discussion. 
Narrator: Having a home bank will enable her to save and she will be less tempted to use her money.

(II) Narrator: What are the advantages of saving at home for Rafiqah? Mentor, pause and lead the discussion.

Narrator: The advantages of saving at home for Rafiqah are; she is less tempted to use her money; easier to hide the money from other people and she can easily use the money for other things to help her family.

(II) Narrator: What are the challenges of putting your savings in a home bank? Mentor, pause and lead the discussion.

Narrator: The advantages of putting your savings in a home bank is that you can easily access the money and use whenever you want - whether it is a need or a want.

Narrator: Now, let us listen to the story of Rafiqah's cousin called Muna.

\section{The Story of Muna}

Muna wants to save some money to enroll in a club in her school but she needs some money for registration, She decides to hide her 50 Shillings under her mattress where she sleeps. Like Rafiqah, she also fetches water for her uncle sometimes.

Muna is easily tempted by sweets and biscuits she sees in the market. So, about once a month, she takes a little money from under her mattress. That makes her so happy! And sometimes, when she has fetched water, she puts the money back under her mattress.

One day, her uncle sees her put the money under the mattress, and he demands that she gives him 30 shillings one day to buy food. Her sister's chore is to sweep under the mattresses, so sometimes she takes money from Muna and uses it for her transport. The money also has gotten mixed up with dust and dirt. When the time comes to pay the first installment for the environment club, Muna realizes that she does not have enough money under her mattress. 
(II) Narrator: How does keeping money under her mattress make it harder for Muna to save? Mentor, pause and lead the discussion.

Narrator: Keeping money under a mattress will make it hard for Muna to save because others who need money will pressure her to give it to them; It can be easily stolen or borrowed.

(II) Narrator: What are the advantages of saving under the mattress for Muna? Mentor, pause and lead the discussion.

Narrator: The advantages of saving under a mattress is that she has easy access to her money that she can spend on things she wants or use to help her family.

(11) Narrator: Which place do you choose for saving your money? Why? Mentor, pause and allow the girls to discuss their choice for savings realistically and help them compare the options and think about the best and safest place for their own savings.

Narrator: In rural Wajir where there no other options for saving such as banks, saving in a home bank serves as the nearest and most efficient in their context. The objective of the lesson is to help them compare the options and think about the best and safest place for their own savings.

(II) Narrator: We are almost coming to the end of today's session. The mentor will now pause, answer your questions and respond to any confusing issues.

Narrator: Thank you for participating in today's session. See you next week! 


\section{Session 6: Learning about Home Banks}

Narrator: Hello girls. Today, we will learn about home banks and how to keep them safe and also gain skills on record keeping in relation to home banking.

Narrator: Mentor, for this session you will need a blackboard, chalk OR flipchart markers.

Narrator: The session will take about 1 hour and 30 minutes.

(II) Narrator: Mentor, pause and ask the participants to share what they learned in the last session. Be sure to clarify any confusing issues.

(11) Narrator: Before, we begin the session, let us have a volunteer to lead us in an energizer. Mentor, pause an invite one of the participants to lead the rest in an energizer. Remember, you can always pause the recording at any point of the session and conduct an energizer.

(II) Narrator: Who can tell what a home bank is? Mentor, pause and lead the discussion.

Narrator: A home bank is a safe place where people keep their money at home. It is a container or box that is custom made to store money; Can have a lock or not.

Narrator: A home bank sometimes called penny (coin) bank or money box is the traditional name of a coin container used for saving money mainly coins but it can also be used to store notes. It can help you to reach your savings goals by putting money for savings away and out of reach.

(II) Narrator: Stand up if you know someone who has a home bank. Mentor, pause and allow the participants to stand up.

(II) Narrator: Can we have volunteers to can share about the person and their home bank (how they got or made the home bank, where they keep it, when they started saving and how much they have saved since they started using it? Mentor, pause and lead the discussion. Once the discussion comes to an end, ask the participants to sit down.

(11) Narrator: Stand up if you have a home bank. Mentor, pause and allow the participants to stand up. Can we have volunteers to describe their experience using the home bank that is how you got/ made the home bank, where you keep it, when you started saving and how much you have saved since you started using it? Mentor, pause and lead the discussion. Once the discussion comes to an end, ask the participants to sit down.

Narrator: Thank you for sharing your experience. We will now talk about how to keep your home bank safe. 
Narrator: It is possible to save money at home in a home bank like our volunteers who have shared their experiences. However, it is very important to identify a safe place where one can keep their home bank so that they don't lose their savings.

II Narrator: What are some of the safe places at home you as girls can keep a home bank? Let the girls give you the options and list them on a flip chart depending on their answers consider the advantages and disadvantages and help them think and list only safe places, explaining why some areas may not be good to store the home bank. Mentor, you can now pause and lead the discussion.

Narrator: Safety of a home bank entails;

1. Accessibility. Meaning, girls should store their home banks in places where they can access it, and also keep in mind that not everyone should know where the box is

2. Information meaning, who to tell and who not to tell about the home bank

3. Away from theft and destruction

Narrator: We will now discuss the second section of today's session which is recording keeping of savings.

Narrator: As we have learnt from previous sessions, it is important to keep written records of your plans about your money. In this section, we will learn about a very simple table that will help you keep track of how much money you have in your home bank and how much you have spent.

(II) Narrator: Mentor, pause and draw a table with 5 columns and 6 rows on a flipchart or blackboard.

Narrator: Mentor, at the top of column write money in, on the second column write money out, on the third write calculations and on the top of the last column write new total.

Narrator: We will now practice how to use the table for record keeping. Mentor, please write $1^{\text {st }}$ August 2015 , on the money in column write Kshs 300 , on the money out column write Kshs 50 , on the calculation column write $300-50=250$ - this gives us the amount on the new total column which is Kshs 250.

(II) Narrator: Mentor, on the second row please write $11^{\text {th }}$ August 2015 on the date column, 100 on the money in column, 0 on the money out column and on the calculation column write 100 which is money in on $1^{\text {st }}$ August +250 which was the new total on $1^{\text {st }}$ August -0 which was the money out. The new total is therefore $100+250-0=350$. Mentor, please pause and work out with the girl the new total on $16^{\text {th }}$ August if money in was Kshs 50 and money out was 100. 
Narrator: I hope you now know how to keep records of your savings. In this last section of today's session, we will give each one of you a home bank and Kshs 300 to help you practice how to use the record keeping table and also to practice budgeting and saving at home.

(II) Narrator: Mentor, pause and distribute the home banks and $300 \mathrm{Kshs}$ to each girl. Make sure they sign for the items.

Narrator: I hope you like your home banks! Please take ten minutes and think about how you will use the $300 \mathrm{Kshs.}$

$>$ Do you have a financial goal that you will top up the $300 \mathrm{Kshs}$ to reach? How will you get the additional money?

$>$ Do you have expenses that you will use the $300 \mathrm{Kshs}$. for? If so, how will you budget your money so that the 300 Kshs. doesn't get used up right away?

(II) Narrator: Mentor, pause and divide the girls into pairs and have them share their plans with their partner.

(II) Narrator: Mentor pause and ask 2-3 pairs to share their plans.

Narrator: Now that we have been learning about how important it is to save, we encourage everyone to use these home banks to keep your savings, We also hope that you will use the initial $300 \mathrm{Kshs}$. as a start to reach a financial goal or to practice your budgeting skills.

II Narrator: Thank you for your active participation in today's session. The mentor will now pause to answer your questions and clarify any confusing issues.

Narrator: I hope you learnt something new in today's session. See you next week! 
Narrator: Hello, welcome to today's session! Today, we will talk about the different options for earning money.

Narrator: Mentor, for this session you will need a blackboard and chalk OR flipchart and markers.

Narrator: The session will take about 1 hour.

Narrator: Mentor, ask participants to share what they learnt during the last session. Remember to add anything that they have left out and clarify any confusing issues. You can now pause, listen and provide feedback.

Narrator: We will begin the session with a game that will help us to think about some of the current ways that girls like you earn money. In this game, I am going to mention 3 different ways of earning money. If you have any experience with the ways of earning money that I mention, I will ask you to perform an action, and then give me an example of that way of earning money. Mentor, pause and explain the game.

Narrator: I hope you have understood the game. If anyone in this group has ever earned money by doing a small job for someone else - please stand up and jump. Mentor, pause and allow girls to do the action. Those who have stood up and jumped give us an example of a small job you have ever done for someone else. Mentor, pause lead the discussion then allow the girls to sit down.

(11) Narrator: If anyone in this group has ever earned money by buying and selling things - stand up and clap your hands. Mentor, pause and allow girls to do the action. Now can a few of those who have stood and clapped their hands give us an example of the things you bought and sold to earn money? Mentor, pause lead the discussion then allow the girls to sit down.

(II) Narrator: If anyone has ever made something or grown something themselves and then sold it to earn money - please stand up and spin around. Mentor, pause and allow girls to do the action. Now let's ask a few of those who stood up and spun around to give us an example of something they or grown something themselves and then sold it to earn money. Mentor, pause lead the discussion then allow the girls to sit down.

(II) Narrator: We can certainly see that girls in our group have lots of experience with different ways to earn money - I wonder how many of you have had experience with all three ways of earning money that is doing small jobs, buying and selling things, and making or growing something to sell. If anyone here has experience doing all three of these things to earn money - then please stand up jump up, hop on one foot, clap your hands, and spin around (all at the same time!!). Mentor, pause and allow girls to do the actions.

Narrator: You are good examples of how hard girls work to earn money to help their families and to reach their own goals. 
Narrator: Now that we know about our existing experience in earning money - let's spend some time exploring ways that we can earn more money doing the same kinds of activities. To help us get started I would like to tell you a story about a girl called Munira. Please listen carefully because I will ask you questions at the end of the story.

\section{The Story of Munira}

Munira needed money to help buy food for her family and meet her personal goals, so she started a business of making jewelry from beads and selling it to people in the market. At first business was good, but then more and more young people started to copy Munira (even some of her friends) - and business started to drop.

One thing Munira noticed was that many customers bought matching sandals from another vendor after buying her beads - so she started to sell both jewelry and sandals (giving a special price for people who bought both), and that helped grow her business again.

Next, she started to ask her customers what preferences they had regarding the beads and most of them preferred beads of mixed colors and matching sandals. So Munira started mixing the beads when making the jewelry, and matching them to respective pairs of sandals. This kept most of her customers very loyal to her (and made it easier to sell more too!!)

Finally, Munira paid close attention whenever she travelled to other markets to see if anyone was trying something new when it came to selling beads and sandals. That is where she first found out about a woman selling cheaper raw materials (beads for the jewelry and leather for the sandals). She started buying the raw materials from the woman, hence increasing her profits and at the same time reducing the cost of producing jewelry and sandals. However, she realized that she needed to save and purchase a sack of beads in bulk, as they were always getting more expensive. 
(II) Narrator: Now that you have listened to Munira's story. I would like to ask you a few questions. The first question is why was Munira trying to earn some money? Mentor, pause and lead the discussion.

Narrator: Very good, Munira was trying to earn money to help buy food for her family.

(II) Narrator: Second question is, what business did she start at first? And what challenge did she run into? Mentor, pause and lead the discussion.

Narrator: Well done! Munira started a business of making beaded jewelry. The challenge she faced was that others copied her business and started making and selling jewelry, so her business dropped.

(II) Narrator: The last question is, what were some things she did to try and earn more money? Mentor, pause and lead the discussion.

Narrator: Good! Munira tried;

[(i) Adding variety to the product/service she was selling (selling matching sandals);

(ii) Asking her customers about improvements she could make;

(iii) Keeping her eyes and ears open for new ideas, and improved methods - such as buying beads in bulk

Narrator: Next, let's see if we can use one of Munira's strategies to improve one of our own existing ways of earning money. Working with the person on your left, please talk about one of your current ways of earning money - and decide on an example of how you could use of one of Munira's three strategies to increase your earnings. Remember that her strategies involve:

(i) Adding variety to the product/service she was selling;

(ii) Asking her customers about improvements she could make;

(iii) Keeping her eyes and ears open for new ideas, and improved methods

(II) Mentor, pause explain the exercise and give the girls 10 minutes to discuss in pairs. After 10 minutes, ask few volunteers to share their business improvement strategies.

(II) Narrator: We will now take a break and conduct an energizer. Mentor, pause and request a volunteer to conduct an energizer.

Narrator: Welcome back! Now that we have spoken about ways to improve our existing ways of earning money, let's spend a little bit of time considering new ways to earn money. During today's session (both the game at the start, and the activity we just completed) we have been hearing about lots of different ways girls in our group earn money. So now, let's take a few minutes to use each other as a source of good information and advice about new ways to earn money that we can add to our existing ways of earning money, or use to replace an existing way. 
(II) Narrator: Mentor, pause and invite a few girls to share about a new way of earning money they have heard someone speak about in our group today.

II Narrator: Okay, now why don't you spend 10 minutes talking to your partner to get more information and ideas about just how that way of earning money works? Make sure to talk about what kind of skills and qualities someone needs to succeed at that way of earning money. Mentor, pause and allow the pairs to discuss.

(II) Narrator: Mentor, pause and invite a few pairs to share their feedback.

Narrator: You see - being part of this group is a great source of ideas and support. And who knows, maybe some of you will now be able to both improve an existing way of earning money and/or to start a new one!!

(II) Narrator: We have now come to the end of the session. Before we conclude, please ask the mentor questions or clarifications. Mentor, pause and respond to the questions.

Narrator: I hope you enjoyed today's session. See you next week! Goodbye. 


\section{Session 8: Girls’ Money and the Risky Income Cycle}

Narrator: Hello, welcome to today's session! Today, we will discuss about how girls in our community make and spend money as well as the risks associated with earning and spending money.

Narrator: Mentor, for this session you will need a blackboard and chalk OR flipchart, markers and 2 small pieces of papers for each girl. For example, if you have 20 girls, you will need 20 times 2 pieces of papers which is a total of 40 pieces of papers.

Narrator: The session will take about 1 hour.

Narrator: Mentor, ask participants to share what they learnt during the last session. Remember to add anything that they have left out and clarify any confusing issues. You can now pause, listen and provide feedback

(II) Narrator: Mentor pause and put up a blank piece of flip chart paper on the wall or in the center of the room.

(II) Narrator: Girls, in one of our sessions, we talked about how adults in our community make money. Now we're going to talk about how girls like you make money. Can I have a volunteer to draw a picture of a typical girl in your community? Mentor, pause and select a volunteer. Give the volunteer 5 minutes to draw a picture of a girl. When she completes drawing the picture, ask the group to select a name for the girl.

(II) Narrator: Mentor, pause and handout the pieces of paper you had prepared earlier. Make sure each girl has, at least three pieces of paper.

II Narrator: I hope we all have 2 pieces of paper. On one of the pieces of paper, I want you to write one way that the girl that was draw gets money. Once you're done, come and paste your papers (or put them down if the flip chart is on the floor) on the left side of the girl. Mentor, pause and clarify the exercise then give the girls 5 minutes to write and place their pieces of paper.

(II) Narrator: On the second piece of paper, I want you to write one thing that the girl in the picture spends money on. Once you're done, come and paste your cards or put them down if the flip chart is on the floor) on the right side of the girl. Mentor, pause and clarify the exercise then give the girls 5 minutes to write and place their pieces of paper.

(II) Narrator: Mentor, now pause and invite the girls to come gather around the picture of the girl." 
Narrator: Mentor, once they have gathered round the picture, start with the right side. Have the girls help you organize the cards into piles of common expenses. For example clothes, food, sanitary towels, school fees, school supplies, rent, among others. Ask the girls to help you to move around the expenses and put the most common expenses on top, followed by somewhat common, and then on the bottom the least common expenses. Pause and guide the exercise.

Narrator: Now that you have agreed on the order of expenses from most common to least common, I would like to ask you a few questions about the girl in the picture. The first question is, about how much does the girl spend in a week and month on the expenses you have identified? Mentor, pick the common expenses, pause and lead the discussion.

(II) Narrator: The second question is, why does she spend money on those particular items? Mentor pause and lead the discussion.

Narrator: Now that we have agreed how the girl in the picture spends her money, we will now discuss how the girl earns her money.

(II) Narrator: Mentor, now pause and invite the girls to come gather around the picture of the girl."

Narrator: Mentor, once they have gathered round the picture, start with the left side. Have the girls help you organize the cards into sources of money starting by grouping according to similar sources of cash (i.e. pocket money from parents, boyfriends, casual chores, etc.), and then have them rank the sources of income by most common to least common.

Narrator: Now that we have agreed on the different sources of the girl's income, I would like to ask you a few questions. About how much does a girl get from the various sources of money in a month? How often does she get this income - Daily? Weekly? Monthly and can someone describe more about each of these sources of money? Mentor, pick the common sources of income, pause and lead the discussion.

(II) Narrator: Do you think it matters where this money comes from? Mentor, pause and lead the discussion.

Narrator: From the different ways that "name of girl" gets money, which are some that might have some risks to them? Risky means anything that puts you into trouble with your parents, teachers and any other authority.

Narrator: From the risky sources of income mentioned, what makes this way of getting money risky? Mentor, pause and lead the discussion.

(II) Narrator: What can the girl do to avoid some of these risks? Mentor, pause and lead the discussion. 
Narrator: Some of the risky sources that you might have mentioned are;

1. If you have borrowed money from a friend and you can't repay in good time

2. Stealing money from your parents, friends or classmates

3. Not retuning change from the shop/market when your parents send you

(11) Narrator: If the girl had her own money that she kept aside as savings at her home, how would this change the risk that comes with some of the ways of getting money that we discussed? Mentor, pause and lead the discussion.

Narrator: When you are in this situation or feeling like you "owe" someone something for the money that you borrowed, you live in fear and are uncomfortable until you are able to repay that money. Therefore, we can try to think about our savings as a way that we can use our own money so that we do not have to rely on borrowed money to meet our needs.

(II) Narrator: Does anyone have a story or an example of when something like this happened? Let's remember to keep confidentiality and not use anyone's names. Mentor, pause and listen to the a few experiences.

Narrator: Thanks you very much for sharing your experiences! Before we come to the end of today's session, please ask the mentor any questions or to clarify issues that are not clear.

Narrator: Thank you very much for participating in today's session. See you next week! 


\section{Session 9: Know the Difference between Needs and Wants}

Narrator: Hello girls. Today, we will learn about the difference between needs and wants.

Narrator: Mentor, for this session you will need a blackboard, chalk OR flipchart markers.

Narrator: The session will take about 1 hour and 30 minutes.

(11) Narrator: Mentor, pause and ask the participants to share what they learned in the last session. Be sure to clarify any confusing issues.

Narrator: Before, we begin the session, let us have a volunteer to lead us in an energizer. Mentor, pause an invite one of the participants to lead the rest in an energizer. Remember, you can always pause the recording at any point of the session and conduct an energizer.

Narrator: We will begin the session with an interesting game that will help us identify wants and needs.

II Narrator: We will write the letters of two words with our bodies. Ready? Move your heads in the air to 'write' the word "need" the way you would move a pen on a piece of paper. Mentor, pause and allow participants to write the word.

(II) Narrator: Now, I would like you to write the word "wants" with your knees. Ready? Mentor, pause and allow participants to write the word.

Narrator: We spend money on many things. Some of these things are necessary for our survival. These things are called NEEDS. Others are things that we want, and when we buy them, we are happy. We call these things WANTS. Today, we are going to discuss the difference between the things that we want and the things that we need. One part of controlling what we spend knows the difference between wants and needs.

II Narrator: Mentor, pause and choose two places in your room or area to represent "wants" and "needs" so that girls can form a line between the two places. If you are outside, pick two objects. Alternatively, you could ask two girls to represent needs and wants and stand in two different spots.

II Narrator: I'm going to mention an expense, something that we could spend money on. Your job is to decide if this expense is a WANT or NEED. The mentor will pause and wait for everyone to agree. If you think that the expense is only a need, place yourself close to the object [or person] that represents NEEDS. If you think that the expense is only a want and can never be considered as a need, place yourself close to the object [or person] that represents WANTS. But if you are not sure, or you think that in some cases, the expense could be either a want or a need, place yourself somewhere in the middle 
of the two objects [or people]. For example, if I say "Bangles", and you think that it is more of a want than a need, you can move and stand at the 'wants' section or person representing "wants". Mentor, pause and explain the exercise.

Narrator: I hope we have now understood the exercise. I will now mention different needs and wants, your work is to move to the needs or wants section. Are you ready?

II Narrator Water. Is it a need or want? Mentor, pause and allow the girls to move to the relevant section. After the girls have chosen their place along the line, ask 1 or 2 of them in different spots to explain why they chose to stand where they did.

(11) Narrator: A second pair of shoes. Is it a need or want? Mentor, pause and allow the girls to move to the relevant section. After the girls have chosen their place along the line, ask 1 or 2 of them in different spots to explain why they chose to stand where they did.

(II) Narrator: Bus fare. Is it a need or want? Mentor, pause and allow the girls to move to the relevant section. After the girls have chosen their place along the line, ask 1 or 2 of them in different spots to explain why they chose to stand where they did.

(II) Narrator: Hijab. Is it a need or want? Mentor, pause and allow the girls to move to the relevant section. After the girls have chosen their place along the line, ask 1 or 2 of them in different spots to explain why they chose to stand where they did.

(11) Narrator: Food. Is it a need or want? Mentor, pause and allow the girls to move to the relevant section. After the girls have chosen their place along the line, ask 1 or 2 of them in different spots to explain why they chose to stand where they did.

(II) Narrator: Rent. Is it a need or want? Mentor, pause and allow the girls to move to the relevant section. After the girls have chosen their place along the line, ask 1 or 2 of them in different spots to explain why they chose to stand where they did.

(11) Narrator: Money to start a business. Is it a need or want? Mentor, pause and allow the girls to move to the relevant section. After the girls have chosen their place along the line, ask 1 or 2 of them in different spots to explain why they chose to stand where they did.

(11) Narrator: Sweets. Is it a need or want? Mentor, pause and allow the girls to move to the relevant section. After the girls have chosen their place along the line, ask 1 or 2 of them in different spots to explain why they chose to stand where they did.

(II) Narrator: Are wants and needs the same for everyone? Mentor, pause and lead the discussion. 
Narrator: Wants and needs are often different for different people. But, to manage our money well, we have to decide what needs and wants are for us. The key to saving is making good decisions about spending our money. If you can spend less money and save even just a little bit, you will attain your savings goals in the end. Your short-term loss can become your long-term gain.

Narrator: I will now tell you a story about two girls called Abida and Latifa to help girls tyou understand the difference between wants and needs. Please pay attention.

The Story of Abida and Latifa
Abida and Latifa work together to assist their elderly uncle to fetch water for the cattle. In return the uncle gives them each Kshs. 20
per week for the good work. The girls are able to earn at least Kshs. 60 per month.
Abida spends all of her money each month buying new clothes whenever she accompanies her mother to the market. Sometimes she
helps her friends when they need money, Abida also buys perfume and body lotions whenever she has some money in her pocket,
and she never saves any money.
Latifa saves Ksh 50 each month. It has not been easy, but she has cut down on spending money a lot. Instead of buying perfume and
lotion, she decided to continue using the small Vaseline her mother buys her once in a while. She has also decided to wait a few
months before buying a new pair of shoes. Even though she still gives some money to her mother for household needs, she has found
that it is possible for her to save a little money by differentiating her wants from needs.


Narrator: I hope you enjoyed the story. I will now ask you some questions about the story.

(II) Narrator: How does Abida manage her money? Mentor, pause and lead the discussion.

Narrator: Abida spends all her money, mostly on things that she wants like lotion and perfume.

(11) Narrator: How does Latifa manage her money? Mentor, pause and lead the discussion.

Narrator: Latifa saves most of her money, and she has cut down on her spending, too. She spends mostly on needs - she gives some to her mother for household expenses, and spends a small amount on herself.

(II) Narrator: Are you more like Abida or Latifa? Why? Mentor, pause and lead the discussion.

Narrator: We are almost coming to the end of today's session. Next time, we will keep talking about the Eight Steps for Savings. Until then, pay close attention to what you spend money on!

(II) Narrator: Mentor, pause and respond to any questions and clarify any confusing issues.

Narrator: Thank you for participating in today's session. See you next week! 


\section{Session 10: Control Spending}

Narrator: Hello girls. Today, we will learn how to control our spending and gain practical skills of making a personal budget.

Narrator: Mentor, for this session you will need a blackboard, chalk OR flipchart markers and 10 stones or 10 sticks or10 pieces of paper for each girl.

Narrator: The session will take about 1 hour and 30 minutes.

(II) Narrator: Mentor, pause and ask the participants to share what they learned in the last session. Be sure to clarify any confusing issues.

(11) Narrator: Before, we begin the session, let us have a volunteer to lead us in an energizer. Mentor, pause an invite one of the participants to lead the rest in an energizer. Remember, you can always pause the recording at any point of the session and conduct an energizer.

(II) Narrator: Mentor pause and ask girls to sit in a circle or gather round so that everyone can see. Give each girl 10 stones (or sticks, or pieces of paper) and tell them that each one represents 10 Shillings - so take care of them!!

Narrator: I hope we all have 10 stones or 10 sticks or 10 pieces of paper. We are going to play a game called the Spending Game. In this game you are going to have a series of opportunities to spend the 100 Shillings the mentor has given you - which you can imagine that you earned doing some small jobs for me. Each of you will make your own choices - and there is no right or wrong way to spend your money. Are you ready to play the game?

Narrator: I want all of you to imagine that it is Saturday and you have decided to go to the market to buy a new outfit. You each have 100 Shillings that you earned from fetching water for your neighbor. Mentor, as the girls spend money, make a note of what each one buys from you.

(II) Narrator: It is hot and your feet are tired. A lorry driver asks if you want a ride to and from the market today-it just costs 10 shillings. Pay the mentor 10 shillings if you accept his offer and then take a quick drive to the market (or just keep walking on your tired feet). Mentor, pause and let the girl who want to pay hand you 10 shillings.

(11) Narrator: You arrive at the market (in the lorry or by foot) and you see that some of your friends are already there. Your best friend asks if you have enough money to buy you and her something to eat. Pay the mentor 10 Shillings if you decide to buy you and your friend some lunch (or just tell her that you are not hungry and keep moving). Mentor, pause and let the girl who want to pay hand you 10 shillings. 
(II) Narrator: While you are heading towards your favorite shop a new shop catches your eye. He has some very attractive dresses for sale-and matching sandals. The price is only 80 Shillings but he says you have to decide right away as he only has a few outfits available. Pay the mentor 80 Shillings to buy the dress and sandals from him or move on (and only let the first three girls buy from him as his supply is limited). Mentor, pause and let the girl who want to pay hand you 10 shillings.

II Narrator: Next you go to your favorite shop where the owner knows you and gives you good prices. She has some very nice dresses for 50 Shillings-and a good supply. Pay the mentor 50 Shillings to buy a dress. Mentor, pause and let the girl who want to pay hand you 10 shillings.

(11) Narrator: Now you are looking for shoes—but it is hard to find one that match your new dress. You go to another shop and the perfect shoes cost 40 Shillings. Pay the mentor 40 Shillings to buy shoes—or move on. Mentor, pause and let the girl who want to pay hand you 10 shillings.

II Narrator: You remember that you have run out of soap and lotion at home and you see a very good price to buy one of each for just 10 Shillings. Pay the mentor 10 Shillings or miss out on this good price. Mentor, pause and let the girl who want to pay hand you 10 shillings.

II Narrator: You are feeling unlucky when it comes to buying a new outfit when suddenly you see that there is a new trader in the market form Garissa who has very special prices_ you can buy a dress, shoes, and a necklace for 70 Shillings. Pay the mentor 70 Shillings to buy them. Mentor, pause and let the girl who want to pay hand you 10 shillings.

II Narrator: You are getting ready to go home when you see that your Auntie is in the market. She asks if she can borrow 10 Shillings from you to buy some medicine as she is not feeling well. Pay the mentor 10 Shillings if you lend the money to her. Mentor, pause and let the girl who want to pay hand you 10 shillings.

(II) Narrator: On your way to leave the market you see a woman beside a broken down lorry selling dresses for 30 Shillings and shoes for only 20 Shillings (a special price because she needs to raise money to fix her lorry immediately). Pay the mentor 30 Shillings to buy a dress and 20 Shillings to buy shoes at this very special price. Mentor, pause and let the girl who want to pay hand you 10 shillings.

Narrator: Now it is time to go home. If you paid for a ride with the lorry driver, then go home with him. If not, then enjoy the walk home...

Narrator: Thank you for playing the game. Hope you enjoyed it!

(II) Narrator: What did you end up spending your money on? And did you save any? Mentor, pause and lead the discussion. 
(II) Narrator: How did you make your decisions? Mentor, pause and lead the discussion.

(II) Narrator: Are you happy with how you spent your money? Mentor, pause and lead the discussion.

Narrator: Now that you have thought about your spending decisions, it is time to learn about something called a "budget". A budget is a really useful tool to help. We can use it to plan both our "money coming in" and our "money going out" over a period of time. It can help us to spend our money wisely, and to save more money that we might without it.

Narrator: A budget is simply our planned "money coming in" and how we will spend that money over a period of time - like a week or a month.

Narrator: Now, we will learn about a budget that one we could all use to track our actual money in and money out over a typical week.

(II) Narrator: Mentor pause and draw a simple budget. Please draw 2 columns and 7 rows on a flip chart or a blackboard.

(11) Narrator: Mentor pause and write "money in" at the top of the column on your right and Kshs 100 on the second row of the column on your right.

Narrator: Mentor, next write "money out" on the second row on the column on the on your left. Then on the rows under the money out section write on each row
1. Transport
2. Food
3. Clothing
4. Soap/Lotion

(II) Narrator: Mentor, pause and allow the girls to draw a budget like the one you have drawn on their books.

(II) Narrator: Now let's work with another group member to plan for Round Two of the Spending Game. We will all start out with the same amount of money (100 Shillings) which we can put in our "money in" row- and will have the same choices to make. But this time we have a chance to plan ahead and make a budget. So take a few minutes to "budget" how you will use your 100 Shillings - and then we will quickly go through the same steps for the game. Please remember to fill in the budget that you have just drawn. Mentor pause explain the exercise and allow the girls to think how they would spend the 100 shillings. 
(II) Narrator: Mentor pause and ask girls to sit in a circle or gather round so that everyone can see. Give each girl 10 stones (or sticks, or pieces of paper) and tell them that each one represents 10 Shillings - so take care of them!!

Narrator: I hope we all have 10 stones or 10 sticks. We are going to play a game Spending Game again. In this game you are going to have a series of opportunities to spend the 100 Shillings the mentor has given you - which you can imagine that you earned doing some small jobs for me. Each of you will make your own choices - and there is no right or wrong way to spend your money. Are you ready to play the game?

Narrator: I want all of you to imagine that it is Saturday and you have decided to go to the market to buy a new outfit. You each have 100 Shillings that you earned from fetching water for your neighbor. Mentor, as the girls spend money, make a note of what each one buys from you.

(11) Narrator: It is hot and your feet are tired. A lorry driver asks if you want a ride to and from the market today-it just costs 10 shillings. Pay the mentor 10 shillings if you accept his offer and then take a quick drive to the market (or just keep walking on your tired feet). Mentor, pause and let the girl who want to pay hand you 10 shillings.

(II) Narrator: You arrive at the market (in the lorry or by foot) and you see that some of your friends are already there. Your best friend asks if you have enough money to buy you and her something to eat. Pay the mentor 10 Shillings if you decide to buy you and your friend some lunch (or just tell her that you are not hungry and keep moving). Mentor, pause and let the girl who want to pay hand you 10 shillings.

(II) Narrator: While you are heading towards your favorite shop a new shop catches your eye. He has some very attractive dresses for sale-and matching sandals. The price is only 80 Shillings but he says you have to decide right away as he only has a few outfits available. Pay the mentor 80 Shillings to buy the dress and sandals from him or move on (and only let the first three girls buy from him as his supply is limited). Mentor, pause and let the girl who want to pay hand you 10 shillings.

(II) Narrator: Next you go to your favorite shop where the owner knows you and gives you good prices. She has some very nice dresses for 50 Shillings-and a good supply. Pay the mentor 50 Shillings to buy a dress. Mentor, pause and let the girl who want to pay hand you 10 shillings.

(II) Narrator: Now you are looking for shoes_-but it is hard to find one that match your new dress. You go to another shop and the perfect shoes cost 40 Shillings. Pay the mentor 40 Shillings to buy shoes-or move on. Mentor, pause and let the girl who want to pay hand you 10 shillings.

(II) Narrator: You remember that you have run out of soap and lotion at home and you see a very good price to buy one of each for just 10 Shillings. Pay the mentor 10 Shillings or miss out on this good price. Mentor, pause and let the girl who want to pay hand you 10 shillings. 
(11) Narrator: You are feeling unlucky when it comes to buying a new outfit when suddenly you see that there is a new trader in the market form Garissa who has very special prices- you can buy a dress, shoes, and a necklace for 70 Shillings. Pay the mentor 70 Shillings to buy them. Mentor, pause and let the girl who want to pay hand you 10 shillings.

(11) Narrator: You are getting ready to go home when you see that your Auntie is in the market. She asks if she can borrow 10 Shillings from you to buy some medicine as she is not feeling well. Pay the mentor 10 Shillings if you lend the money to her. Mentor, pause and let the girl who want to pay hand you 10 shillings.

(II) Narrator: On your way to leave the market you see a woman beside a broken down lorry selling dresses for 30 Shillings and shoes for only 20 Shillings (a special price because she needs to raise money to fix her lorry immediately). Pay the mentor 30 Shillings to buy a dress and 20 Shillings to buy shoes at this very special price. Mentor, pause and let the girl who want to pay hand you 10 shillings.

(II) Narrator: What did you end up spending your money on? And did you save any? Mentor, pause and lead the discussion.

(II) Narrator: How did you make your decisions this time? Were they different or the same? Mentor, pause and lead the discussion.

(II) Narrator: Are you happier with how you spent your money this time? Why? Mentor, pause and lead the discussion.

(II) Narrator: Mentor, pause and give the girls 10 minutes to try to make a personal budget for the coming week. Girls, think about what "money-in" you will have next week. That is money that you get from different sources. Then think about what you will spend next week that is money out.

Narrator: Good job! A budget is something that you can use to plan, and can be updating as your money in and money out change. That is, if you get money from new or different sources, or spends it on different things, or in different amounts. Practice at home as making a budget, and sticking to it, takes practice!

Narrator: Remember, if you don't have enough money in, you may have to reduce what you spend. If you have more money coming in than what you will spend, you can always save! Don't worry if this seems hard. Just start by writing down what you spend, that is the first step to having a good budget.

Narrator: Before we leave, I want to give you two rules for savings. Repeat after me! Spend less than you earn! Mentor, pause.

(II) Narrator: Repeat after me! Save a little every week! Mentor, pause. 
Narrator: If you follow those simple rules that you have repeated, your savings are sure to grow!

(II) Narrator: Mentor, pause and respond to any questions and clarify any confusing issues.

Narrator: Thank you for participating in today's session. See 


\section{Session 11: Think About the Future: Money in and Money Out}

Narrator: Hello girls. Today, we will talk about how to plan for our money in and money out

Narrator: Mentor, for this session you will need a blackboard, chalk OR flipchart markers

Narrator: The session will take about 1 hour and 30 minutes.

II Narrator: Mentor, pause and ask the participants to share what they learned in the last session. Be sure to clarify any confusing issues.

II Narrator: Before, we begin the session, let us have a volunteer to lead us in an energizer. Mentor, pause an invite one of the participants to lead the rest in an energizer. Remember, you can always pause the recording at any point of the session and conduct an energizer.

Narrator: The "Savings Step of the Day" is: Think about the Future: Money in and Money Out! Another way to say "money coming in" is "income", and another way to say "money going out" is expenses.

Narrator: I will now tell you about a girl called Naima. Please pay attention because I will ask you questions at the end if the story.

\section{Naima's Story}

Naima is a 14-year-old girl who works hard at her studies and to help her family, but she also really enjoys fashion. She has been dreaming of getting a new hijab, but she knows that she can't ask her parents to get one for her. In addition to school, Naima usually works 1 or 2 days a week helping her aunt to fetch water from the government borehole that is quite a distance from their home. Her auntie gives her at least 20 Shillings a day. Each week, Naima thinks about what she needs to spend money on to help her family, like food, paraffin for the lamp, and charcoal, as well as some personal needs like Vaseline.

But, sometimes, she will keep a little extra in her home bank just in case she fails to get work in the coming week, or some other need for money comes up - as it usually does! However, every once in a while, Naima finds herself with a small amount of extra pocket money and then she puts it aside to save up and buy a hijab. 
(11) Narrator: I will now ask you some questions related to the story. How does Naima earn money? Mentor, pause and lead the discussion.

Narrator: Naima earns money by helping her aunt.

(II) Narrator: How does she manage the money she earns? That is her money coming in or income? Mentor, pause and lead the discussion.

Narrator: Naima thinks about her expenses for the week first, saves in her home bank for weeks with no income or unexpected expenses.

(II) Narrator: How does planning ahead help Naima? Mentor, pause and lead the discussion.

Narrator: Planning ahead helps Naima meet her needs, and save for some of her wants for example the hijab.

(II) Narrator: We will now talk about planning ahead. Mentor, pause and divide girls into groups of 3 or 4 .

Narrator: I hope we are all in groups. You have heard the story of Naima. She thinks ahead about what she needs to buy and sets aside her money for those needs. Your job is to work together and create a very short story about a girl (or girls) who are NOT like Naima. That is, the girls in your story should do the opposite of Naima. The girls in your story will NOT know how much they earn and NOT plan ahead for the things they need to buy. While you can think about things you know in real life, please don't use anyone's real name or situation in your story. Come up with a fake name to protect the person who didn't plan! You have 10 minutes to come up with a story together. Mentor, circulate while girls are planning to make sure that everyone understands the task, and to keep them on track. Pause and allocate the girls 10 minutes for the task.

Narrator: I hope you have completed the task. Mentor pause and ask a volunteer from each group to tell her story. Remember to clap for each group!

(II) Narrator: Have you seen any girls in your community who are more like - Naima, or the girls in the stories you developed? Mentor, pause and lead the discussion.

(II) Narrator: What are some specific things that make them more like Naima or the girls in these stories? Mentor, pause and lead the discussion.

(II) Narrator: What can they do to be more like Naima, and plan ahead? Mentor, pause and lead the discussion. 
Narrator: For girls to plan ahead, they need to use their budget, think about their expenses before they make them, spend less than they earn, save money with their group, save money at home.

(II) Narrator: We have now come to the end of the session. Mentor, pause and respond to any questions and clarify any confusing issues.

Narrator: Thank you for participating in today's session. See you next! 


\section{Session 12: Save Regularly!}

Narrator: Hello girls. Today, we will talk about saving regularly.

Narrator: Mentor, for this session you will need a blackboard, chalk OR flipchart markers

Narrator: The session will take about 1 hour and 30 minutes.

(II) Narrator: Mentor, pause and ask the participants to share what they learned in the last session. Be sure to clarify any confusing issues.

(11) Narrator: Before, we begin the session, let us have a volunteer to lead us in an energizer. Mentor, pause an invite one of the participants to lead the rest in an energizer. Remember, you can always pause the recording at any point of the session and conduct an energizer.

(II) Narrator: Mentor, pause and pick two girls, or ask for two volunteers to stand in two places at the front of the room. Tell everyone that one girl represents "True" while the other represents "False."

Narrator: We will play a game where you will have to stand up and go behind one of these girls. This time, I will give you a series of statements about saving. For each statement, you must decide if you think it is true or false. If you think the statement is true, stand behind the girl who represents true. If you think it is false, stand behind the girl who represents false. If you are not sure, make your best guess.

(II) Narrator: Let's do an example to make sure everyone understands. I will give you a statement. Think about the statement for just a moment, and then move to the place along the line that shows your answer. The statement is saving money can help you in the future. Mentor, pause and give the girls 1 minute to move.

(II) Narrator: Mentor, when everyone has chosen a place, ask 2 girls - one from the "true" side, one from the "false" side - to explain why they chose that spot. Mentor, pause and allow volunteers to explain.

Narrator: The statement is "false", because it depends on the individual's needs.

Narrator: I hope we have now understood the activity. The first statement is; you have to have a large sum of money to save. Is the statement true or false? Mentor, pause and allow the girls to move to relevant positions. Once they have chosen their positions, ask 1 or 2 volunteers to explain why they think the statement is true or false. 
Narrator: The statement is false. You can save even small amounts of money.

Narrator: Saving every week requires discipline. Is the statement true or false? Mentor, pause and allow the girls to move to relevant positions. Once they have chosen their positions, ask 1 or 2 volunteers to explain why they think the statement is true or false.

Narrator: The statement is true. Saving every week requires discipline.

(11) Narrator: Saving tiny amounts of money is a waste of time. Is the statement true or false? Mentor, pause and allow the girls to move to relevant positions. Once they have chosen their positions, ask 1 or 2 volunteers to explain why they think the statement is true or false.

Narrator: The statement is False - even small amounts add up with time.

(II) Narrator: You should only save the money you have left over at the end of the week or month. Is the statement true or false? Mentor, pause and allow the girls to move to relevant positions. Once they have chosen their positions, ask 1 or 2 volunteers to explain why they think the statement is true or false.

Narrator: The statement is false. it is best to save before you spend.

(II) Narrator: Saving a little bit of money each week will eventually result in a larger amount of money you can use for something important to you. Is the statement true or false? Mentor, pause and allow the girls to move to relevant positions. Once they have chosen their positions, ask 1 or 2 volunteers to explain why they think the statement is true or false.

Narrator: The statement is true.

(II) Narrator: Girls like me do not have enough money to save. Is the statement true or false? Mentor, pause and allow the girls to move to relevant positions. Once they have chosen their positions, ask 1 or 2 volunteers to explain why they think the statement is true or false.

Narrator: The statement is false. most girls have at least a small amount they can put aside to save.

II Narrator: Girls should not have to save money; their parents should save for them. Is the statement true or false? Mentor, pause and allow the girls to move to relevant positions. Once they have chosen their positions, ask 1 or 2 volunteers to explain why they think the statement is true or false.

Narrator: The statement is false. Everyone has emergencies and future needs, so girls should save too.

Narrator: Saving is hard to do when there is not enough money to pay for all the things we need. However, saving can be easier when you decide to save regularly. Even if you can only save a little bit on a regular basis, making saving a habit will slowly build up a sum of money and help you reach your goals. 
Narrator: I will now tell you a story about two cousins called Aisha and Baysan. Please pay attention.

\section{Two Cousins Save}

Aisha and Baysan are cousins who live next door to each other. They decide that they can make some money making and selling necklaces. Since they need the initial materials the two girls make a promise to start saving so they can buy the necessary items. They know exactly what they want to buy and its price. They decide to save weekly and together agree that when they have 1000 Shillings in total they will be able to start their business.

Baysan is good at math - the cousins promise to each save 50 Shillings every week. So, they will save a total of 100 Shillings each week. That means that they need to save for 10 weeks before they can buy start the business. It seems like a long time, but by putting their savings together, it will make it easier to realize their goal.

For the first few weeks, both cousins make sacrifices in order to save, and their family congratulates them! But, Aisha becomes tempted and buys a new piece of jewelry. Then, she also uses some of her money to take transport to the nearby shops instead of walking.

The next week, when Baysan asks Aisha for her savings, Aisha just shrugs and says she can't afford to save right now. She promises to give Baysan a bigger sum of money later, after she makes more savings. "Don't worry," she says, "I'll work hard and save a lot next month. It will all work out the same." 
(II) Narrator: I hope you enjoyed the story! What happened to the girls' savings plan? Mentor, pause and lead the discussion.

Narrator: The girls weren't able to follow their savings plan when Aisha found other things to spend the money on.

(II) Narrator: Why is Aisha having a hard time saving every week? Mentor, pause and lead the discussion.

Narrator: Aisha had other things to spend on; she had to help her sick mother one week.

(II) Narrator: What do you think about Aisha's plan to collect a larger amount of money later? Mentor, pause and lead the discussion.

Narrator: Aisha's plan might not work because she might find it difficult to save a larger amount of money that she did not plan for, and then the girls' plans will fail. She might also think about changing the spending decisions she has easy control over like going to a variety show.

(II) Narrator: What are girls' chances starting their business making necklaces? Mentor, pause and lead the discussion.

Narrator: Their chances are probably not good based on what has happened with Aisha.

(II) Narrator: How would things work out differently for Aisha and Baysan if they were members of a savings group or had a home bank? Mentor, pause and lead the discussion.

Narrator: The group encourages discipline to save regularly.

(II) Narrator: Before we conclude today's session, the mentor will pause, respond to your questions and clarify and confusing issues.

Narrator: I hope you enjoyed today's session. See you next week. Bye! 


\section{Session 13: Dealing with Setbacks in Saving}

Narrator: Hello, welcome to today's session! Today, we will talk about dealing with setbacks in saving.

Narrator: Mentor, for this session you will need a blackboard and chalk OR flipchart, markers.

Narrator: The session will take about 1 hour.

II Narrator: Mentor, ask participants to share what they learnt during the last session. Remember to add anything that they have left out and clarify any confusing issues. You can now pause, listen and provide feedback.

Narrator: In our previous sessions, we talked about how to develop a savings plan. A savings plan is an idea about how you are going to accomplish your savings goals and the action you will take to achieve those goals.

(II) Narrator: What is your savings plan and which actions are going to take to achieve your savings goal. Mentor, pause and guide the discussion.

Narrator: We are now going to explore challenges and possible setbacks in saving. Saving is not always as easy as it seems and sometimes, things may not go as planned. In the previous sessions, we talked about making a savings plan which helps us to achieve our saving goals. When we make our savings plan, we must always be aware of the challenges and possible setbacks to our savings plan.

(II) Narrator: What is a setback? Mentor, pause and lead the discussion.

Narrator: A setback is an event or a happening that prevents your plan from working out. This is likely to affect your plan.

(II) Narrator: What are some of the examples that may be a setback to a savings plan? Mentor, pause and lead the discussion.

Narrator: Some examples of setbacks are;

- Asmat plans to be saving 10 Shillings per week from her school pocket money, but suddenly, the school undergoes an indefinite closure due to a measles outbreak in the school community, and 'no school' means no 'pocket money'.

- Another example is; Fazia, who lives with her mother and three younger siblings, has been saving 15 Shillings each week so that she can afford a new hijab for Id UI Fitr. However, her mother's goats were stolen and she needs to help her buy at least one goat. 
Narrator: We are now going to talk about how you can deal with Setbacks in Saving. I will begin by telling you a story about a girl who had a good savings plan but things did not work out as she expected. But most importantly, we are going to discuss how she learned to deal with setbacks to her savings plan.

Narrator: The girl's name is Halima so listen attentively to the story.

\section{Halima's Story}

Halima is a 14 year old girl in class 7 living with her elder sister in Wajir. She would like to save enough money so that she can start a small henna applying business. She will use some of her income for her school items because she can't always depend on her sister to provide them. She knows that she will need to earn some money so that she can buy the initial items she needs.

Halima washes her neighbor's clothes and fetches water to earn at least 20 shillings per week. She manages to save 200 Shillings in 6 weeks. Just before Halima sets off to buy henna for her business, her sister falls ill and she has to use the 200 Shillings for medicine.

But Halima does not give up. She begins saving for her capital again and manages again, even though this time it takes even longer ( 9 weeks). She finally manages and buys a small container of henna that she can apply people during her cousins wedding. She makes good money and is able to buy more henna and keep her business going. However, a few of her friends also decide to start henna applying business, so she starts getting fewer and fewer customers.

To keep her business alive so she can keep saving, Halima decides to re-invest some of the money she made applying henna at the wedding into selling small bead bracelets that women buy after they've had henna applied, and is able to make enough money not only to help her buy school items, but also buy more henna and bracelets to keep the business going.

(II) Narrator: What was Halima's saving goals? Mentor, pause and listen to the responses.

Narrator: Very good. Halima's savings goal was to start a henna business.

(II) Narrator: What was Halima's savings plan? Mentor, pause and listen to the responses. 
Narrator: Halima planned to raise 200 Shillings by doing chores, then use the money to start a henna business.

(II) Narrator: What were the setbacks in Halima's savings plan? Mentor, pause and listen to the responses.

Narrator: Halima's sister fell sick; her friends also started applying henna and her business went down.

(II) Narrator: How did Halima overcome her various setbacks? Mentor, pause and listen guide the discussion.

Narrator: Halima overcame difficulties in raising capital by re-adjusted her timeframe for the savings goal because she was not able to save as much each week as she had initially planned. When Halima used her savings for an emergency, she begun saving all over again. Halima also came up with an additional way of making money for her capital and overall, she kept saving and did not give up.

Narrator: One thing that will help you in dealing with setbacks in savings is having a "fall back plan." This plan involves five simple steps that will help you manage a setback in your saving: This steps are;

1. Re-visit your savings plan

2. Explore and List your available options

3. Weigh your options and compare them to your savings goal

4. Choose your fall back plan

5. Continue saving and don't give up!

(II) Narrator: We are almost coming to the end of today's session. Before we do so, please ask your mentor any questions. Mentor, pause and respond to questions.

Narrator: Thank you very much for your active participation in this session. See you next week. Goodbye! 


\section{Session 14: Your Own Money vs. Someone Else's Money}

Narrator: Hello, welcome to today's session! Today, we will talk about your own money vs. someone else's money.

Narrator: Mentor, for this session you will need a blackboard and chalk OR flipchart, markers.

Narrator: The session will take about 2 hours.

Narrator: Mentor, ask participants to share what they learnt during the last session. Remember to add anything that they have left out and clarify any confusing issues. You can now pause, listen and provide feedback

(II) Narrator: Thank you very much for sharing what you learnt last week. Before we begin today's session, we will conduct an energizer. Mentor, pause and request a volunteer to lead the group in an energizer of her own choice.

(II) Narrator: I hope you enjoyed the energizer. We have spent a lot of time learning about why it is important to save and how to increase our savings. But sometimes we also borrow money. In the next few meetings, we will try to understand the difference between money we save and money we borrow. Mentor, pause and ask the girls to stand up and make one line.

(II) Narrator: I hope we are all in a line. Now, I am going to tell you different amounts of money and where they came from. For each one, you must decide if that money is borrowed or if it is your own money. If you think it is borrowed, take one step forward. If you think it is your own money, take one step backward. Mentor, pause and clarify the activity.

(II) Narrator: Now that we have all understood the activity, am going to read out the statements. Remember if you think it is borrowed, take one step forward. If you think it is your own money, take one step backward. The first question is you are given money to buy clothes and you save 20 shillings. Mentor pause and allow the girls to move.

(II) Narrator: The answer is own money. Question two, your sister loans you 50 Shillings to buy body lotion. Mentor pause and allow the girls to move.

(II) Narrator: The answer is borrowed money. Question three, you sell your jewelry at 60 Shillings to a friend. Mentor pause and allow the girls to move.

(II) Narrator: The answer is own money. Question four, at the market milk costs 50 Shillings a litre and you buy it on credit. Mentor pause and allow the girls to move. 
(II) Narrator: The answer is borrowed money. Question five, you borrow 10 shillings to buy a lost exercise book Mentor pause and allow the girls to move.

(II) Narrator: The answer is borrowed money. Question six, your aunt gives you a gift of 20 Shillings Mentor pause and allow the girls to move.

(II) Narrator: The answer is own money. The last question is, you take 200 Shillings from your home bank locked up in your suitcase to buy sanitary pads. Mentor pause and allow the girls to move.

Narrator. The answer is own money. Thank you for participating in the activity. I hope it was fun! We will now move to the next activity.

(11) Narrator: Mentor, pause and divide the group into two teams and give each team a name. Use something familiar or humorous for the teams: names of animals ("the goats" vs. "the camels"). Mentor, draw two columns on the blackboard or flipchart and write names of the teams on either columns.

(11) Narrator: I would like us to play a game about borrowed money. The team who the question is directed to will have 1 minute to discuss the answer. If they get the answer right, the mentor will award them one mark. If they get it wrong, the mentor will award them zero marks. Mentor, pause and explain the activity.

(II) Narrator: I hope the activity is now clear. We will start with Team 1. Ready? Why is borrowed money different from your own money? Mentor pause and allow the team 1 minute to discuss.

(II) Narrator: The answer is borrowed money has to be paid back; you have more flexibility and control with your own money. Mentor, pause and award 1 mark if the answer is right and zero if it is wrong.

(II) Narrator: Team 2, question number two is yours. Are you ready? When you borrow money, why do you have to pay it back? Mentor pause and allow the team 1 minute to discuss.

(II) Narrator: The answer is because the money does not belong to you; the money belongs to the person or institution who lent it to you, who expects to get it back. Mentor, pause and award 1 mark if the answer is right and zero if it is wrong.

(II) Narrator: Question number 3 goes to team one. If you borrow money from a friend, do you have to repay it? Mentor pause and allow the team 1 minute to discuss. 
(11) Narrator: The answer is normally, yes. Sometimes a family member or friend will end up giving you the money - that is, giving you permission to not repay the loan. But you should never assume that this will happen, and always plan to repay or return whatever you borrow. Mentor, pause and award 1 mark if the answer is right and zero if it is wrong.

(11) Narrator: Question 4 goes to team two. When you borrow money from a friend, can you decide when to pay it back? Mentor pause and allow the team 1 minute to discuss.

Narrator: The answer is maybe. If you borrow from a friend or relative, they may be very flexible about when you need to return the money. You will have to discuss the terms and schedule before you borrow the money. Mentor, pause and award 1 mark if the answer is right and zero if it is wrong.

(II) Narrator: Question 5 goes to team one. When you borrow money from a financial institution (like a bank) or a savings group, can you decide when to pay it back? Mentor, pause and allow the team 1 minute to discuss.

(II) Narrator: The answer is No. If you borrow from a financial institution or a group, you will most likely have a payment schedule to repay in installments that are due each week or each month until the full amount is repaid. Mentor, pause and award 1 mark if the answer is right and zero if it is wrong.

(11) Narrator: Question 6 goes to team two. Does it cost you anything to borrow money from a friend or family member? Mentor, pause and allow the team 1 minute to discuss.

(11) Narrator: The answer is it depends. When you borrow from a friend or family member, she may not ask you to pay interest on the loan. Again, this is something you will have to discuss before you borrow the money. Mentor, pause and award 1 mark if the answer is right and zero if it is wrong.

(II) Narrator: Question 7 goes to team one. Does it cost you anything to borrow money from a financial institution or a savings group? Mentor, pause and allow the team 1 minute to discuss.

(II) Narrator: The answer is yes, most lenders charge you something to use their money (this amount is "interest". Mentor, pause and award 1 mark if the answer is right and zero if it is wrong.

(II) Narrator: The last question goes to team two. If you borrow money and a thief then steals it, do you still have to repay the money? Mentor, pause and allow the team 1 minute to discuss.

(II) Narrator: The answer is yes. Mentor, pause and award 1 mark if the answer is right and zero if it is wrong 
Narrator: Congratulation teams! The point of the game was to understand that money comes with responsibility - to pay it back, to pay it back on time, and to pay it back with any interest that might be charged.

(II) Narrator: I will now conclude the exercise by asking you a few questions. What are some advantages of borrowing money? Mentor pause and lead the discussion.

Narrator: Some of the advantages you have mentioned are; you have immediate access to money; you can buy what you want right away; you will not miss the chance to buy something or make an investment at a good price.

(II) Narrator: What are some disadvantages? Mentor pause and lead the discussion.

Narrator: Some of the disadvantages you have mentioned are; borrowing costs money because of interest and/or fees; if you fail to repay there are consequences; there is pressure to repay on time; if there is an emergency you may never be able to repay.

(II) Narrator: I would now like you to ask your mentor any questions you might have about borrowing money. Mentor, pause and lead the discussion.

Narrator: Now that we have talked about one's own money and other people's money, we are going to look at why it is important to ensure that other people respect your own money and understand that you have the right to make your own decisions over it. Let's begin by thinking of some of the ways that sometimes make us feel we don't have control over our own money.

Narrator: I will begin by telling you a few stories and asking you questions after each story. The first story is about a girl called Firdaus. Firdaus has 250 Shillings and plans to buy a watch when she visits her sister in Garissa. Instead, her mother gets the money from her home bank which she had hidden in a cupboard in her room and gives it to a visiting aunt to go to hospital for treatment.

(II) Narrator: How can Firdaus make her mother understand that she needed to discuss with her first before giving the money to someone else and without her permission? Mentor, pause and guide the discussion.

Narrator: I am now going to tell you about a girl called Rehema. Rehema keeps her savings in her home bank and often deposits small amounts of money whenever she has. She hopes to raise some money so she can save up for capital to start a new business in the near future after completing primary school. The mother knows she keeps some money in her home bank and instead of saving for her own business, she tells her to save the money for the family to buy a new jiko (charcoal cooker) for boiling rice for sale at the market.

(II) Narrator: How can Rehema make her mother understand that she plans to use the money for something else? Mentor, pause and lead the discussion. 
Narrator: Now, I will tell you the last story about two girls called Mariam and Saida. Mariam and Saida are best friends and spend a lot of time selling tomatoes at the market together. They know a lot about each other and share almost everything. Mariam knows that Khadija, one of their other friends, borrowed 50 Shillings from Saida two weeks ago. Khadija raises the money and decides to return it to Saida but finds Mariam instead. She gives the money to her knowing that they are best friends but insists that she gives it to Saida upon her return. Mariam decides to use the money and without Saida's permission.

(II) Narrator: How does Saida make Mariam understand that though they are best friends, she had no right to use the money without her permission? Mentor, pause and lead the discussion.

Narrator: Many times we may feel like our own money is not really ours because either other people decide on our behalf what we should do with it or simply have access to it without our permission. These can be our friends, our parents, our siblings, boyfriends who often feel they should have access to our money or make decisions on our behalf. While it is important to help out at home or take on other responsibilities money wise, it is also important that people around you know and respect the fact that they have the responsibility to discuss with you over your money and that you have the right to make the final decision.

(II) Narrator: What can Firdaus, Rehema and Saida do to change their situation? Mentor, pause and lead the discussion.

Narrator: Firdaus, Rehema and Saida can do the following;

1. Communicate their saving goals and what they plan to use the money for clearly. In this way, others will gain an appreciation of what the money is intended for

2. Be open and set limits on other people accessing their money. In this way, others will understand that they don't have the right to access their money

3. Clearly and openly communicate how far they can go in taking up money responsibilities. In this way they won't be raising other people's expectations too high

4. Show responsibility and assertiveness in the decisions they make over the use of their own money. In this way, others will respect them and set their own limits to accessing their money.

(II) Narrator: We are almost coming to the end of today's session. Before we do so, please ask your mentor any questions. Mentor, pause and respond to questions.

Narrator: Thank you very much for your active participation in this session. See you next week! 
Narrator: Hello! Welcome to today's session. In this session, we will talk about money and discuss who we talk to about money.

Narrator: Mentor, for this session you will need a blackboard, chalk OR flipchart markers

Narrator: The session will take about 1 hour and 30 minutes.

(11) Narrator: Mentor, pause and ask the participants to share what they learned in the last session. Be sure to clarify any confusing issues.

(II) Narrator: Before, we begin the session, let us have a volunteer to lead us in an energizer. Mentor, pause an invite one of the participants to lead the rest in an energizer. Remember, you can always pause the recording at any point of the session and conduct an energizer.

Narrator: We will begin the session by playing a game about the who and what of talking about money.

Narrator: We will start by thinking about WHO we talk to about money. You will give those people or a person, and they should stand up and clap their hands if they talk to that person/people about money. Have fun!

(II) Narrator: Stand up clap your hands if you talk to your parents about money. Mentor, pause.

(II) Narrator: Stand up clap your hands if you talk to your siblings about money. Mentor, pause.

III Narrator: Stand up clap your hands if you talk to your shopkeepers about money. Mentor, pause.

(II) Narrator: Stand up clap your hands if you talk to your boss about money. Mentor, pause.

(II) Narrator: Stand up clap your hands if you talk to your friends about money. Mentor, pause.

(II) Narrator: Stand up clap your hands if you talk to your friend about money. Mentor, pause

(II) Narrator: Stand up clap your hands if you talk to your school - mates about money. Mentor, pause.

(II) Narrator: Stand up clap your hands if you talk to your uncles about money. Mentor, pause.

(II) Narrator: Stand up clap your hands if you talk to your aunties about money. Mentor, pause. 
(II) Narrator: Stand up clap your hands if you talk to your neighbors about money. Mentor, pause.

(II) Narrator: Stand up clap your hands if you talk to your grandparents about money. Mentor, pause.

(II) Narrator: Do you have any other people that you talk to about money that can be added to the list? Mentor, pause and lead the discussion.

(II) Narrator: Now, you will think about WHAT you talk about to the people in terms of money. Stand up clap your hands if you talk about; school fees. Mentor, pause.

(II) Narrator: Stand up clap your hands if you talk about; pocket money. Mentor, pause.

(II) Narrator: Stand up clap your hands if you talk about; fees. Mentor, pause.

(II) Narrator: Stand up clap your hands if you talk about; things to buy for the family. Mentor, pause.

(II) Narrator: Stand up clap your hands if you talk about; food. Mentor, pause.

(II) Narrator: Stand up clap your hands if you talk about; bus fare. Mentor, pause.

(II) Narrator: Stand up clap your hands if you talk about; prices of food. Mentor, pause.

(II) Narrator: Stand up clap your hands if you talk about; prices of products. Mentor, pause.

(II) Narrator: Stand up clap your hands if you talk about; saving. Mentor, pause.

(II) Narrator: Stand up clap your hands if you talk about; borrowing money. Mentor, pause.

(II) Narrator: Do you have any other examples of WHAT you talk about. Mentor, pause and lead the discussion.

(II) Narrator: For the final part of the game, you will think about how you feel when you talk about money. Mentor, pause and lead the discussion.

(II) Narrator: Stand up clap your hands if - when you talk about money - you feel confident! Mentor pause.

(II) Narrator: Stand up clap your hands if - when you talk about money - you feel happy! Mentor pause. 
(II) Narrator: Stand up clap your hands if - when you talk about money - you feel nervous! Mentor pause.

(II) Narrator: Stand up clap your hands if - when you talk about money - you feel angry! Mentor pause.

(II) Narrator: Stand up clap your hands if - when you talk about money - you feel hopeful! Mentor pause.

Narrator: Do you have any other examples to add about how you feel when you talk about money?

Narrator: We talk about money with many people in many situations. However, money can be one of the most difficult topics to talk about with other people. Even so, as we saw in the answers to our questions, we still talk about it with many people for many reasons. In the next few sessions, we will learn about some ways to talk about money that make the conversation easier.

Narrator: In this next section, I will explain to you 3 different outcomes that can happen when we talk about money.

Narrator: Win-Win situation. This is the best outcome in any discussion about money. Both people (and groups) involved in the discussion get something or everything they want or need. They both have a positive feeling at the end of the discussion, and are willing to talk about money again in the future.

Narrator: Lose-Lose. This is the worst possible outcome in a discussion about money. In a lose-lose outcome, the two people (or groups) cannot agree. In the end, neither person (nor group) involved in the discussion gets what they wanted. They may not be willing to talk about money again in the future.

Narrator: Win-Lose / Lose-Win. In a win-lose or lose-win situation, one person (or group) gets what she wants and the other gets nothing. When this happens, the loser might be less likely to want to talk to the winner about money again in the future.

Narrator: An outcome is the result of something. When we are talking about money, we use outcome to mean the result of the discussion.

Narrator: Our goal is to find ways to make talking about money easier and more effective. We'll start by identifying the possible outcomes - or results - of talks about money.

(II) Narrator: When we finish talking about money with someone, is everybody involved always happy with the outcome? Mentor, pause and lead the discussion 
Narrator: When we talk about money, sometimes both people involved end up happy as each gets something they want. Sometimes neither gets anything - both lose. And sometimes, one person gets something she wants and the other person does not. When we talk about money, there are winners and losers.

Narrator: I will now give you a few examples of outcomes. Your job is to listen and decide who in each story is happy with the outcome.

Narrator: Situation 1: A customer is discussing the price of a blanket with a vendor in the market. They cannot agree on the price, and the customer leaves the market without buying anything from the vendor.

(II) Narrator: Who was the winner at the end of this discussion? Mentor, pause and lead the discussion.

Narrator: Neither the customer nor the vendor were winners in this case.

(II) Narrator: Who was the loser? Mentor, pause and lead the discussion.

Narrator: Both the vendor and customer were losers.

Narrator: Sometimes, no one involved gets what he or she wants. This type of outcome is called "lose-lose."

(II) Narrator: What are other examples of a "lose-lose" outcome when we talk about money? Mentor, pause and lead the discussion.

Narrator: Situation 2: Minnah wants her sister Zainab to do the housecleaning for her, so that she can spend time with her friend. Zainab asks Minnah to pay her, but Minnah refuses. When Minnah threatens to hit Zainab, Zainab gives in and agrees to do the housework for nothing.

III Narrator: Who was the winner in this discussion? Mentor, pause and lead the discussion.

Narrator: Minnah was the winner

(II) Narrator: Who was the loser? Mentor, pause and lead the discussion.

Narrator: Zainab was the loser. 
Narrator: Often, one person in the discussion gets what he or she wants, and the other gets nothing. These outcomes are called "win-lose" or "lose-win". In those situations, the loser might be less willing to talk with the winner about money again!

(II) Narrator: What is another example of a "win-lose/lose-win" outcome? Mentor, pause and lead the discussion.

(II) Narrator: What are another example of a "win-lose/lose-win" outcome? Mentor, pause and lead the discussion.

Narrator: Another example of a "lose-win" outcome is when you need money immediately and cannot wait. You borrow money from a friend, and she will lend you money ONLY if you agree to pay her back twice as much as you borrowed. In that case, you lose because you do not have time to wait, and your friend wins as she gets more money.

Narrator: Situation 3: Zubaida wants to buy watch. She discusses the price with a salesman in the market but she cannot get the price low enough. She is about to leave when the salesman asks Zubaida to wait for a moment, as he has just remembered another watch he just added to his stock. Zubaida likes it, and it is in her price range. Zubaida decides to buy the second watch.

(II) Narrator: Who was the winner at the end of this discussion? Mentor, pause and lead the discussion.

Narrator: Both Zubaida and the salesman were winners in this situation.

Narrator: This outcome is a "win-win" situation. Both sides got something they wanted or needed, if not everything. In win-win outcomes, everyone comes away with positive feelings and they are likely to talk to each other about money again.

(II) Narrator: What is another example of a "win-win" outcome? Mentor, pause and lead the discussion.

Narrator: Another example is for example of a win-win situation is when you want to buy food from a saleswoman, and you negotiate a good price together. You are happy with your purchase, and your savings, and you recommend that your friends and family buy things from the same saleswoman. She gets more business because of her good offer to you, and you saved some money.

(II) Narrator: Which of the 2 outcomes is the preferred outcome and why? Mentor, pause and lead the discussion.

Narrator: Win- win is preferred because both people in the situation win. They both have positive feelings, and are willing to work together again in the future. 
Narrator: As we come to the end of today's session, pay close attention to the discussions that happen around you every day: at home, with friends, in the market. Ask yourself: Are there winners and losers in this discussion? Do both sides end with something they want? Do both seem happy and satisfied? Or, do they seem angry?

II Narrator: The mentor will now pause and respond to questions and respond to any confusing issues. Mentor, please pause.

Narrator: Thank you for your active participation in today's session. See you next week! 
(II)

Session 16: The DOs and DON'Ts of Talking About Money

Narrator: Hello girls. Today, we will talk about the possible outcomes of discussions about money and identify the Dos and DON'T's of good communication about money.

Narrator: Mentor, for this session you will need a blackboard, chalk OR flipchart markers

Narrator: The session will take about 1 hour and 30 minutes.

(II) Narrator: Mentor, pause and ask the participants to share what they learned in the last session. Be sure to clarify any confusing issues.

II Narrator: Before, we begin the session, let us have a volunteer to lead us in an energizer. Mentor, pause an invite one of the participants to lead the rest in an energizer. Remember, you can always pause the recording at any point of the session and conduct an energizer.

Narrator: We will begin the session by review the possible outcomes of discussions about money that we discussed last week. What types of outcomes are possible when we talk about money? Mentor, pause and lead the discussion.

Narrator: Very good, the possible outcomes of discussions about money are; win -win, win- lose and lose - lose. We said that the best outcome is winwin.

II Narrator: In the last session, I asked you to pay attention to "talking about money" in daily life. Now, who can share with us what type of outcome came from that discussion or talk. Mentor, pause and lead the discussion.

II Narrator: Now, we will play a communication game called the telephone. Can I have 6 girls to come in front. Mentor, pause and let the mentors walk to the front.

(11) Narrator: The girls in front of you will be a telephone line. The mentor will begin the game by whispering a short phrase about any key messages that the girls have learnt about financial education into the first girl's (Girl 1's) ear. Girl 1 will then do her best to repeat the phrase to Girl 2 . Then, Girl 2 will repeat the phrase to Girl 3, and so on until you reach the end of the line. Each girl is allowed to whisper the message ONLY once! And the end of the game, each person will repeat what they heard beginning with the last person to receive the message. Mentor, pause and lead the game. 
(II) Narrator: Now, we will break into equal groups and play the game in our groups. Each group will whisper phrases related to any financial key messages you have learnt. Mentor, pause and divide the girls into groups then give them about 10 minutes to play the game.

(II) Narrator: What happened between the beginning and the end of the line? Mentor, pause and lead the discussion.

Narrator: Good! The message changed or was completely lost.

Narrator: Now, we will talk about the DOs and DON'Ts of good communication skills. Clear communication is very important when it comes to discussing money and financial topics. We don't want our messages to get jumbled or changed or misunderstood because we don't communicate well - especially when we are talking about money, and we want to achieve a win-win outcome.

(II) Narrator: Based on your own experiences, what can happen during a conversation about money to cause a win-lose or lose-lose outcome? Mentor, pause and lead the discussion.

Narrator: Good! One person gets angry; one or both people refuse to listen to the other person; one or both is not flexible or willing to see the other person's point of view.

(II) Narrator: If we want a win-win outcome, what are some Dos or rules we should follow when we talk about money? Mentor, pause and lead the discussion.

Narrator: Some of the Dos or you might have mentioned are;

$$
\begin{aligned}
& \text { DOs for Talking About Money } \\
& \text { - Listen to the other person } \\
& \text { - Try to see the other person's point of view } \\
& \text { - Show respect } \\
& \text { - Be flexible } \\
& \text { - Clearly state what you want }
\end{aligned}
$$

(II) Narrator: Mentor, pause and ask the girls to repeat the Dos. 
(II) Narrator: What should you NOT do when trying to communicate successfully? Mentor, pause and lead the discussion.

Narrator: Some of the Don'ts or you might have mentioned are;

DON'Ts for Talking About Money
- Get angry
- Be rude or insulting
- Reject the other person's ideas without listening
- Lock yourself into one position
- Raise your voice

(II) Narrator: Mentor, pause and ask the girls to repeat the Don'ts.

(II) Narrator: We have now come to the end of today's session. The mentor will pause respond to your questions and clarify any confusing issues. Narrator: Hope you enjoyed today's session. See you next week. Bye. 


\section{Session 17: Resolving Conflicts about Money}

Narrator: Hello girls. Today, we will talk about resolving conflicts about money.

Narrator: Mentor, for this session you will need a blackboard, chalk OR flipchart markers

Narrator: The session will take about 1 hour and 30 minutes.

II Narrator: Mentor, pause and ask the participants to share what they learned in the last session. Be sure to clarify any confusing issues.

II Narrator: Before, we begin the session, let us have a volunteer to lead us in an energizer. Mentor, pause an invite one of the participants to lead the rest in an energizer. Remember, you can always pause the recording at any point of the session and conduct an energizer.

Narrator: We will begin the session by discussing how to apply the do's and don'ts about money in real life.

Narrator: Mentor, pause and ask girls to repeat the DOs and DON'Ts of talking about money from the last meeting. Ask for volunteers to make up a gesture that represents each DOs and DON'T of talking about money. Then have everyone call out the DO or DON'T and repeat the gesture. You can show an example for the first one (e.g. place your hand behind your ear for "Listen to the other person." As a do.

(II) Narrator: Think about the DOs and DON'Ts, and think of a situation in which you did not communicate well with a parent, teacher or friend. What can you do differently in that situation? Girls, the mentor will pause and allow you to discuss with the person seated next to you for 2-3 minutes. Mentor, pause and lead the discussion.

Narrator: People often disagree about issues that involve money. Many of you are starting to have more responsibility for yourself and your financial situation at home, at school, or in your work. That means you will probably have more discussions - and even more conflicts - related to money. Today we are going to talk about and practice resolving conflicts about money.

Narrator: Explain to girls that they will now watch some of the communication skills from the last meeting in action and present the role-play "A Conversation between a Mother and Daughter." Please pay attention because I will ask you questions at the end of the conversation. 


\section{A Conversation Between a Mother and Daughter}

Daughter: Hello, mother. Can I talk to you about something important? Do you have a few minutes now?

Mother: I have to go out soon to work at the stand in the market. Let's make it quick!

Daughter: $\quad$ Mother, l'm thinking its time I went back to school. Most of the girls in our safe space group meetings have gone back to school after we relocated to this village.

Mother: (cutting her off) We have had that conversation before. How much more explaining do I have to do to make you understand that this family is not making enough money for all of you to be in school. It's already hard trying to keep your brothers in school. It just has to wait until there is enough money. Besides you being older, you must be doing something and contribute towards helping the family get around these problems. You know that school costs way more than that

Daughter: $\quad$ But mother, we have been putting my school on hold for two years now. I'm not getting any younger. All my friends are almost completing school now. Does this mean l'm never going back to school?

Mother: $\quad$ Young lady, you do not seem to realize that there are many things that I need to buy for our household. I have to decide how to spend this money in everyone's best interest.

Daughter: I'm sorry. I didn't mean to make you angry. I know it is difficult to manage so many demands on our budget. I can wait to get back into school. Do you think it would be possible for me to come up with a plan to help you pay for my school fees? I'm saving money now, and I am earning some money helping Mama Musa. It isn't much, but if I save, I can make enough to pay half of my schools fees. If I am able to save that money, would you consider helping me pay for the rest?

Mother: $\quad$ That's a good idea I suppose I could consider that. But just remember that we may need to cut down on many other expenses that are not priority right now. 
(II) Narrator: I hope you understood the conversation. What is the daughter's goal for the discussion with her mother? Mentor, pause and lead the discussion. Narrator: Good! The daughters goal is to go back to school.

(II) Narrator: What is the mother's reaction to her daughter? Mentor, pause and lead the discussion.

Narrator: Good job! The mother was at first angry. However, with the daughter's calm explanation, the mother and daughter come to an agreement. Mentor, pause and lead the discussion.

(11) Narrator: What communication skills from our DOs and DON'Ts did you notice? Mentor, pause and lead the discussion.

Narrator: The daughter showed respect, she didn't get angry, she understood her mother's point of view, she was flexible, and she clearly stated what she wanted. She even proposed a new solution when she saw that the first one would not work.

(11) Narrator: I hope you enjoyed today's session. The mentor will now pause respond to your questions and clarify any confusing issues.

Narrator: We have now come to the end of today's session. See you next week! 


\section{Session 18: Role-Play Resolving Conflicts}

Narrator: Hello girls. Today, we will participate in some role plays on resolving conflicts about money.

Narrator: Mentor, for this session you will need a blackboard, chalk OR flipchart markers

Narrator: The session will take about 1 hour and 30 minutes.

II Narrator: Mentor, pause and ask the participants to share what they learned in the last session. Be sure to clarify any confusing issues.

(11) Narrator: Before, we begin the session, let us have a volunteer to lead us in an energizer. Mentor, pause an invite one of the participants to lead the rest in an energizer. Remember, you can always pause the recording at any point of the session and conduct an energizer.

(11) Narrator: Mentor, pause and divide girls into groups of 5.

(II) Narrator: I will assign each group a role play that describes a conflict about money. First, each group should decide together on a win-win solution that will solve your conflict. Then, you will make up a role-play between the people described and the solution you have chosen. At least one of the characters in the role-play should try to demonstrate good communication skills. Mentor, pause and clarify.

Narrator: I will now read out the role play scenario for each group. Please pay attention remember.

Narrator: Group one's scenario is: Ebla helps her grandmother on Saturday morning to feed the cattle and she gets a few small coins in return. She wants to save this money herself. But her mother insists that Ebla give her all of the money to help with household expenses.

[Ebla can discuss the reasons that she is saving money with her mother, and they can agree that keeps half of the money, and gives the other half to her mother.].

(II) Narrator: I will repeat group one's role play once more; Ebla helps her grandmother on Saturday morning to feed the cattle and she gets a few small coins in return. She wants to save this money herself. But her mother insists that Ebla give her all of the money to help with household expenses. 
[Ebla can discuss the reasons that she is saving money with her mother, and they can agree that keeps half of the money, and gives the other half to her (II) mother.]. Mentor, pause and explain.

Narrator: Group 2, here goes your role play. Please pay attention. Fatima gets money each week from her auntie when she fetches for her water early in the morning before school, and saves in her home bank. When her parents learned that Fatima had a little to save at the end of each week, they requested her to be buying some household items.

[Fatima can invite her mentor with her savings program to talk with her parents about the benefits of saving. She can present to them the advantages of saving, and the goals that she has set out for savings. She must make sure to explain that this will save her parents money in the long-term.]

(II) Mentor, pause and explain.

Narrator: I will repeat group 2 role play once again. Fatima gets money each week from her auntie when she fetches for her water early in the morning before school, and saves in her home bank. When her parents learned that Fatima had a little to save at the end of each week, they requested her to be buying some household items.

(II) [Fatima can invite her mentor with her savings program to talk with her parents about the benefits of saving. She can present to them the advantages of saving, and the goals that she has set out for savings. She must make sure to explain that this will save her parents money in the long-term.] Mentor, pause and explain.

Narrator: Finally, group 3, please listen to your role play. Shamim recently worked for a neighbor for 5 days. However, when she went to collect her earnings, the neighbor said she had only worked for 4 days. Shamim wants to resolve the situation and still collect her earnings.

III [Shamim can find someone else who saw her working on each of the 5 days to back up her story. She can tell the neighbor that she is a good worker, and that she wants to continue to do good work for her and that in order to work well, she must be paid.] Mentor, pause and explain.

Narrator: I hope we have all understood our role plays. you have only 10 minutes to prepare a 3-minute role play. Good luck! Mentor pause.

(II) Narrator: Girls, we will now perform our role plays. Please pay attention to what is going on in the role plays because I will ask you questions after all the presentations. Mentor, pause and allow all the groups to perform their role plays.

Narrator: Am sure you have enjoyed the performances. Are you ready for the questions? 
(II) Narrator: What communication skills did you notice among the actors in the role-play? Mentor, pause and lead the discussion.

Narrator: What was the solution they arrived at? Mentor, pause and lead the discussion.

II Narrator: What are other possible solutions to this conflict? Mentor, pause and lead the discussion.

Narrator: Today we have seen different ways of resolving conflicts. In real life, not all discussions about money result in a win-win outcome. Although we all hope for a win-win outcome, sometimes these are impossible due to the personalities involved, or the emotions of the moment. However, communicating with confidence is the starting point for achieving good outcomes when talking about money.

Narrator: As we said in our DOs and DON'Ts, if we explain what we want clearly and listen to the other party's needs, keep calm, and look for a compromise, we can negotiate our way to a win-win outcome more often than not.

(II) Narrator: As we come to the end of today's session, the mentor will pause respond to your questions and clarify any confusing issues. Mentor, pause.

Narrator: I hope you enjoyed today's session. See you next week! 
Narrator: Hello, welcome to today's session which is our last session. In this session, we will talk review our journey to good money management.

Narrator: Mentor, for this session you will need a blackboard and chalk OR flipchart, markers and a ball of string

Narrator: The session will take about 1 hour.

(II) Narrator: Mentor, ask participants to share what they learnt during the last session. Remember to add anything that they have left out and clarify any confusing issues. You can now pause, listen and provide feedback.

Narrator: Thank you very much for sharing what you learnt last week. Before we begin today's session, we will conduct an energizer. Mentor, pause and request a volunteer to lead the group in an energizer of her own choice.

Narrator: At the beginning of our financial education sessions, we spent some time exploring our dreams and looking to the future. We shared our dreams for the future including;

1. Where we were living

2. What we were doing

3. What goals we had reached

4. We also talked about dreams we wanted to achieve in 5 years.

(II) Narrator: Now, I want you to think about your dreams again. Now, close your eyes for a minute and think about yourself five years from now. Mentor, pause and give the participants 1 minutes to think about their dreams.

(II) Narrator: Are your dreams the same as before? Has anything changed about your dreams now? If so, what has changed and why? Mentor, pause and allow a few volunteers to answer the questions.

(II) Narrator: What about your savings goals? Have you had to change your savings goals? Has anyone reached their initial savings goal and set a new one? Mentor, pause and allow a few volunteers to answer the questions. 
Narrator: Thank you for sharing your experiences. Saving is hard, but if you persist you will reach your goals in the end.

Narrator: Over the past months we have been meeting together regularly to try and help each other develop some of the knowledge, skills, and attitudes we need to achieve some of our dreams. We have been exploring ways to make wise decisions about earning, spending, and saving money - all as a way to help us to achieve our dreams. Now that we are at the end of our course, I wanted us to think about a little spider that spends her days dreaming about capturing and eating flies. Sometimes it must seem impossible for her to do. But what does she do to catch them? She makes a web to catch them. The spider patiently weaves together many strands until the web is completed.

(II) Narrator: Now, I want us to see if we can weave together the many things that we have learned these past weeks - to see if we have enough strands in our web to catch our dreams!! For just like the spider, with patience and persistence, plus a few new skills, we can achieve our dreams. To do this we are going to start with a ball of string. Mentor, pause and show them the ball of string.

(II) Narrator: To start weaving our web, I want to see if anyone in our group can share an example of something they have learned about why save money. Mentor, pause and give the ball of string to the first person who responds and let them pass the string on to someone else if there is another girl with an example - with each of them continuing to hold onto the string after they pass it so a web starts to form.

(II) Narrator: The difference between needs and wants. Mentor, pause and have the string passed to one, or two girls, who have an answer with each of them continuing to hold onto the string after they pass it so the web continues to grow.

(II) Narrator: Strategies for saving money regularly? Mentor, pause and have the string passed to one, or two girls, who have an answer with each of them continuing to hold onto the string after they pass it so the web continues to grow.

(II) Narrator: Dealing with setbacks in savings. Mentor, pause and have the string passed to one, or two girls, who have an answer with each of them continuing to hold onto the string after they pass it so the web continues to grow.

(II) Narrator: Talking about money with other people. Mentor, pause and have the string passed to one, or two girls, who have an answer with each of them continuing to hold onto the string after they pass it so the web continues to grow.

Narrator: Dealing with conflicts about money. Mentor, have the string passed to one, or two girls, who have an answer with each of them continuing to hold onto the string after they pass it so the web continues to grow. 
(II) Narrator: Finally, Different ways to earn more money. Mentor, pause and have the string passed to one, or two girls, who have an answer with each of them continuing to hold onto the string after they pass it so the web continues to grow.

II Narrator: Now, let us complete our web by finding out, who has made a new friend in this safe spaces group. Mentor, pause and have the string passed to one, or two girls, who have an answer with each of them continuing to hold onto the string after they pass it so the web continues to grow.

(II) Narrator: Who is a little bit closer to reaching their dream? Mentor, pause and have the string passed to one, or two girls, who have an answer. Make sure that by now everyone is holding the string.

II Narrator: Now look how strong our web is. How much we have learned and grown together. We should all be proud of our efforts and we should celebrate our accomplishments together. So let's dance and sing and celebrate. Mentor, pause and invite girls to share dances \& songs they know, and then perform them with the group. This activity should take at most 20 minutes.

Narrator: Hope you enjoyed the songs and dances! We have now come to the end of today's session which was our last session for financial education. I hope you have learnt skills that will help you to manage your finances better. Thank you for being part of the AGI-K program. Goodbye! 


\section{REFERENCES}

Austrian, Karen and Caroline Sakwa, Financial Literacy Program for the Binti Pamoja Centre, Nairobi, Kenya, 2006.

Bayiga, Julie, David James-Wilson, Kyagaza Esras, and Lisa Parrott, Mobilizing Young People's Resources for Education (DRAFT), Save the Children, Kampala, Uganda, 2009.

Fisher, Roger, William L. Ury and Bruce Patton, Getting to Yes: Negotiating Agreement Without Giving In, 2nd Edition, Houghton Mifflin Co. Boston, MA, 1992.

Fisher, Roger and Scott Brown, Getting Together: Building Relationships As We Negotiate, Penguin Books, NY, 1988.

Global Financial Education Program. Young Women: Your Future, Your Money

Copyright, Microfinance Opportunities, Washington, DC, 2010.

Godfrey, Neale S. and Carolina Edwards, Money Doesn't Grow on Trees: A Parent's Guide to Raising Financially Responsible Children. Children's Financial Networks, Fireside, NY, 1994.

Nelson, Candace, Young People: Your Future, Your Money, Microfinance Opportunities, Washington, DC, 2008.

Nelson, Candace, Jessica Massie and Bailey Butzberger, Jeunes Filles: Votre Avenir, Votre Argent (Financial Education for CARE Burundi), Microfinance Opportunities, Washington, DC, 2010.

Perdomo, Maria. Savings: You Can Do It. Technical Learning Conversations for Avancons Afrique L'Ouest. Freedom from Hunger, Davis, CA, 2008.

Population Council. Dream Big: Kwacha for our Future. Lusaka, Zambia, 2013.

Population Council and Microfinance Opportunities. Young Women: Your Future, Your Money--Workbook for Girls ages 10-14 in Kenya, Nairobi, Kenya, 2011.

Population Council and Microfinance Opportunities. Young Women: Your Future, Your Money--Workbook for Girls ages 15-19 in Kenya, Nairobi, Kenya, 2011.

Population Council and Microfinance Opportunities. Young Women: Your Future, Your Money--Workbook for Girls ages 10-14 in Uganda, Nairobi, Kenya, 2011.

Population Council and Microfinance Opportunities. Young Women: Your Future, Your Money--Workbook for Girls ages 15-19 in Uganda, Nairobi, Kenya 2011 